\title{
Baddeleyite U-Pb ages and geochemistry of the 1875-1835 Ma Black Hills Dyke Swarm across north-eastern South Africa: part of a trans-Kalahari Craton back-arc setting?
}

\author{
JOHAN R. OLSSON ${ }^{1}$, MARTIN B. KLAUSEN ${ }^{2 *}$, MIKE A. HAMILTON ${ }^{3}$, NADINE MÄRZ $^{1}$, ULF SÖDER-LUND ${ }^{1,4}$ AND R. \\ JAMES ROBERTS ${ }^{5}$
}

\begin{abstract}
${ }^{1}$ Department of Geology, Lund University, Sölvegatan 12, SE 22362 Lund, Sweden; ${ }^{2}$ Department of Earth Sciences, University of Stellenbosch, Private Bag X1, Matieland 7602, South Africa; ${ }^{3}$ Jack Satterly Geochro-nology Laboratory, Department of Geology, University of Toronto, 22 Russell Street, Toronto, ON M5S 3B1, Canada; ${ }^{4}$ Laboratory for Isotope Geology, Swedish Museum of Natural History, Box 50 007, SE-104 05 Stock-holm, Sweden; ${ }^{5}$ Department of Geology, University of Pretoria, Private bag X20, Hatfield, Pretoria 0028, South Africa
\end{abstract}

\begin{abstract}
Eleven new baddeleyite U-Pb crystallisation ages and associated whole-rock geochemistry on NE-NNEtrending tholeiitic dykes cutting across the north-eastern corner of the Archaean Kaapvaal Craton, the overlying Transvaal basin and the Bushveld and Phalaborwa igneous complexes collective-ly define a 1875-1835 Ma Black Hills Dyke Swarm (BHDS). Dyke ages do not discriminate between dyke trends or geographic location, but subdivide the BHDS into an older set of four more primitive dykes $(\mathrm{MgO}=9.4-6.8 \mathrm{wt} . \%)$ and a younger set of seven dykes with more differentiated compositions $(\mathrm{MgO}=5.6-4.2 \mathrm{wt} . \%)$. Despite being emplaced over a $c .40 \mathrm{Myr}$ period, major element compositions are remarkably consistent with a single inversely modelled bulk fractionating assemblage of $57.5 \%$ plagi-oclase, $29.5 \%$ augite and 13.0\% olivine. This fractionating assemblage requires an additional assimilation of bulk continental crust (at a low rvalue of 0.2) for reversed modelling of parental rare earth elements. Even though this crustal assimilation indicates that primary magmas could potentially have been derived from a spinel-bearing ambient primordial and asthenospheric mantle source, anomalously low $\mathrm{Nb}$ and high $\mathrm{Pb}$ values for the more primitive older dykes may also have been inherited from a sub-continental lithospheric mantle source. The ages for the BHDS bridge a gap between $c .1889$ and 1867 Ma mafic sills and c. 1830 Ma rhyodacitic pyroclasts, interbedded in the top of a $\sim 3 \mathrm{~km}$-thick Sibasa basalt sequence, which combine into a continuous $c$. 1.89-1.83 Ga igneous province. Similar geochemical signatures are consistent with all sills, volcanic rocks and BHDS feeders collectively belonging to a very voluminous and coherent igneous province, which arguably formed behind active Magondi and Okwa-Kheis arcs, along the western margin of the proto-Kalahari Craton.
\end{abstract}

Keywords: U-Pb baddeleyite dating; geochemistry; mafic dyke swarm; Kaapvaal Craton

\section{Introduction}

Large volumes of predominantly mantle-derived mafic magma emplaced during major events are often recognised as Large Igneous Provinces (LIPs), as per Coffin \& Eldholm's (1994) original definition for well-constrained Phanerozoic examples and subsequent reviews of ancient examples (Ernst 2014). Contentious petrogenetic links to mantle plume sources have, however, led to more stringent criteria concerning the durations of such events (e.g., Bryan \& Ernst 2008). This may ultimately lead to a distinction between continental breakup-related LIPs of short durations, recording more intense magma emplacements, and more long-lived (pulsating?), but still relatively voluminous, magmatic events within potentially different petrotectonic settings. If such a distinction can be made, then it naturally becomes important to properly determine the age span of large igneous events, just as it remains important to consider all other evidence that may shed light on the tectonic setting wherein magmas were formed, differentiated and emplaced. Higher resolution geochronology, better palaeomagnetic constraints, and petrogenetic 

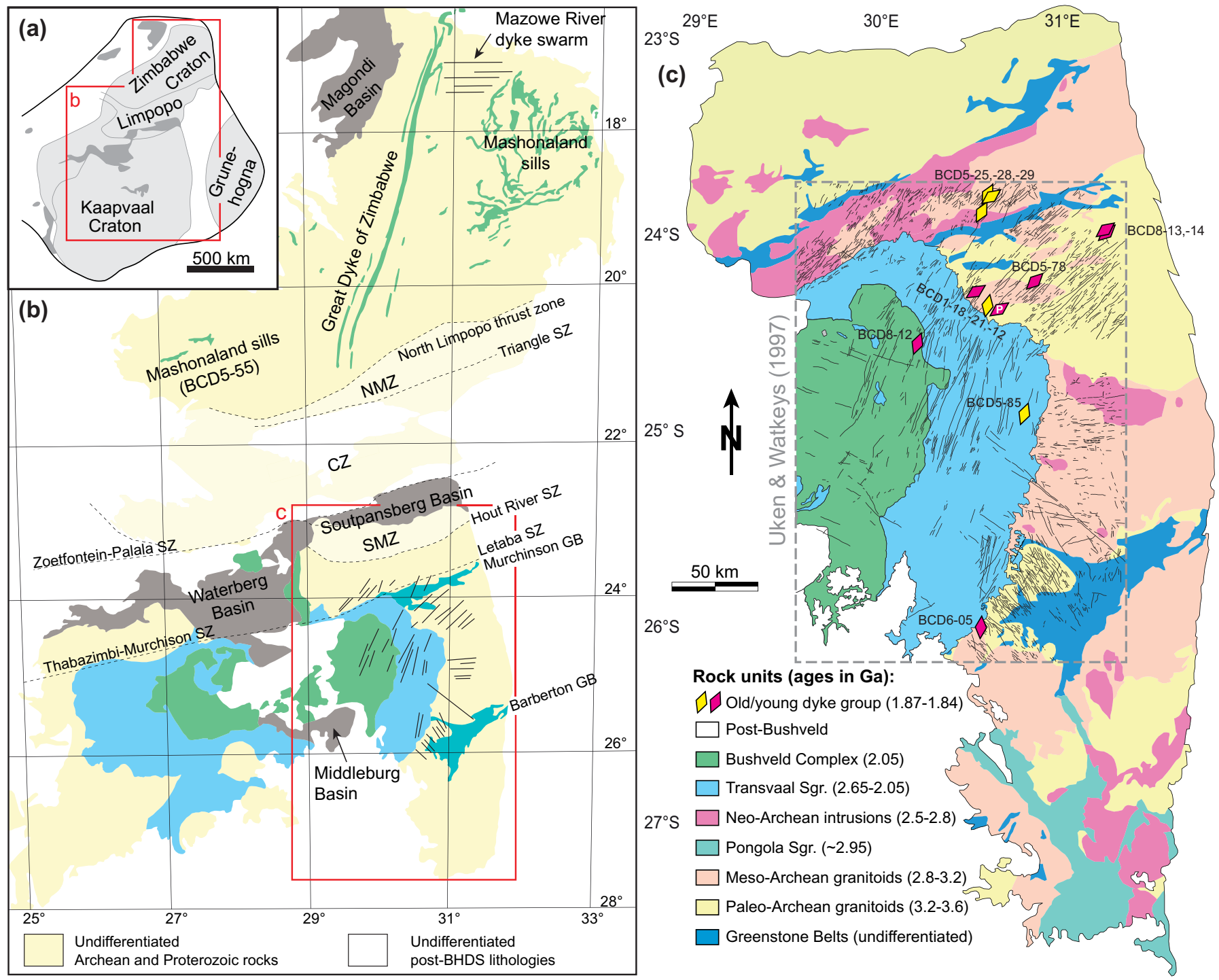

Fig. 1. Geological maps displaying A. an inset of the proto-Kalahari Craton at c. 1750 Ma, shown in more detail in Fig. 9(B), B. pre-1.8 Ga rocks across both the Zimbabwe and the Kaapvaal Craton, adjoined along the Limpopo Mobile Belt, and C. more details of exposed eastern part of the Kaapvaal Craton, as well as overlying eastern lobes of the Transvaal Supergroup and the Bushveld Complex. In (B), labelled large-scale shear (and fault) zones (SZ) are adopted from Rigby et al. (2011). Only the major Barberton and Murchison Greenstone Belts (GB) are shown. The Limpopo Mobile Belt is divided into the Northern Marginal Zone (NMZ), the Central Zone (CZ) and the Southern Marginal Zone (SMZ). Mashonaland sill sample BCD5-55 was collected from the south-western corner of the Zimbabwe Craton. In (C), the geology of Kaapvaal's Archaean basement follows Robb et al. (2006; modified from Klausen et al. 2010). A traced version of Uken and Watkeys' (1997) dyke map is added inside the dashed grey rectangle. Labelled diamonds locate dated dyke samples and are oriented according to the sampled dyke's trend. Different colours relate to a relatively older (yellow) and younger (magenta) sub-swarm, as explained in the text. P identifies one plagioclase-phyric sample.

studies of magma compositions and compilations of basic field relationships, all contribute towards improved reconstruction of petrotectonic settings.

High-precision geochronology represents our most powerful tool whereby igneous feeders have recently been linked to all major volcanic sequences up through South Africa's remarkably well-preserved Mesoarchaean to Palaeoproterozoic stratigraphy. Building on pioneering papers like Hanson et al. (2004a) and Olsson et al. $(2010,2011)$, this paper is the last in a more recent series of six companion papers that provide detailed accounts of prolonged and possibly episodic records of enhanced magmatism at c. 2.93-2.86 Ga (Gumsley et al. 2013, 2015), c. 2.70-2.66 Ga (Gumsley et al. this volume), c. $2.06 \mathrm{Ga}$ (Wabo, de Kock, Klausen, et al. this volume Wabo, de Kock, Humbert, et al. this volume), c. 1.93-1.91 Ga (Alebouyeh et al. this volume) and c. $1.88-1.83 \mathrm{Ga}$ (this paper) affecting the Kaapvaal Craton. Though most of these magmatic events represent sub-episodes within two Archaean ("Pongola" and "Ventersdorp") events, the two younger examples arguably represent subepisodes of the same lesser known episode of trans-Kalahari Craton magmatism, which concludes a $c .1 .2$ billion-year long and nearly continuous stratigraphic record in South Africa, and arguably follows upon the amalgamation of the proto-Kalahari Craton (Fig. 1(A)) within a greater Columbia (Nuna) supercontinent.

The late stage, post-Bushveld magmatic event detailed in this paper is relatively unknown amongst Kalahari Craton workers, but 
is indicated by a number of different studies. Apart from the stratigraphical control exerted by volcanic rocks inside the Olifanshoek Supergroup (Moen 2006) and the Soutpansberg Group (Barker et al. 2006), the first post-Bushveld intrusions to be recognised on the proto-Kalahari Craton were the Mashonaland sills, extending across the north-eastern Zimbabwe Craton (Fig. 1(B)). These sills were dated on the basis of $\mathrm{Rb}-\mathrm{Sr}$ isochrons by Compston and McElhinny (1975) and Cahen et al. (1984) to be c. 1.9-1.8 Ga, and later investigated geochemically by Stubbs et al. (1999). Hanson et al. (2004a) provided the first high-precision U-Pb ages on c. 1.88-1.87 Ga Waterberg-hosted dolerite sills on the Kaapvaal Craton, which were palaeomagnetically and/or geochemically matched to Mashonaland sills and Soutpansberg volcanic rocks.

During earlier stages of a dating campaign - initiated in 2007 by the Universities of Lund, KwaZulu-Natal and Moscow - on mafic dyke swarms across the Kaapvaal Craton, Olsson (2012) discovered the first NE-trending c. 1.9 Ga dyke (1844.4 $\pm 2.6 \mathrm{Ma}$, BCD1-12 in this paper). This unpublished and preliminary age was used by Klausen et al. (2010) in a first attempt to discriminate between dyke generations on the basis of geochemical characteristics, and Lubnina et al. (2010) to calculate a palaeopole for the craton at that time period (sample NL28 in their study). These publications suggested that the name Black Hills Dyke Swarm (BHDS) should be given to NE-trending, c. $1.9 \mathrm{Ga}$, tholeiitic dykes which cut across this part of the craton in great numbers. In the same special volume, Söderlund et al. (2010) dated a pair of Mashonaland sills that were shown to be coeval to Hanson et al.'s (2004a) post-Waterberg sills, and thereby conclusively linked these two cratons at that time. More recently, Geng et al. (2014) constrained a maximum age for more evolved pyroclastic rocks in the uppermost part of the Sibane Formation lavas within the Soutpansberg Group, which will be shown to possibly mark the termination of a $c$. 1.89-1.83 Ga trans-Kalahari Craton igneous province, initiated by the oldest Mashonaland and Post-Waterberg sills.

Our investigation into the magmatic trans-Kalahari Craton event builds on März's (2011) MSc thesis, is modified from an unpublished chapter of Olsson's (2012) $\mathrm{PhD}$ thesis, and focuses on the $\mathrm{U}-\mathrm{Pb}$ baddeleyite $\left(\mathrm{ZrO}_{2}\right)$ dating and geochemical characterisation of 11 NE-NNE-trending mafic dykes cutting across the exposed north-eastern corner of the Kaapvaal Craton (Fig. $1(\mathrm{~B}, \mathrm{C}))$. This paper combines structural, geochronological and geochemical results in order to (1) define the $c .1875-1835 \mathrm{Ma}$ emplacement age span for the BHDS, (2) constrain the petrogenesis and differentiation of its magmas, (3) link the oldest Mashonaland and post-Waterberg sills to the youngest Soutpansberg volcanic rocks within a coherent $c$. 50 Myr-long trans-Kalahari craton magmatic event, and (4) evaluate the nature of the tectonic regime operating during the emplacement of these dykes.

\section{Geological setting}

The Kalahari Craton, into which the BHDS is emplaced, formed around a nucleus of the Palaeo- to early Mesoarchaean Kaapvaal and Zimbabwe Cratons (Fig. 1(A)), which are still connected along a WSW-ENE-trending Limpopo Mobile Belt (Fig. 1(B)). This craton preserves a remarkably continuous geological record of late Mesoarchaean to early Palaeoproterozoic volcano-sedimentary strata in the central parts of the Kaapvaal block, partly intruded by the $c .2 .06 \mathrm{Ga}$ Bushveld Complex, and capped by slightly younger Waterberg-Soutpansberg sediments with inter- bedded lavas. Evidence from unconformably overlying Phanerozoic Karoo sediments and their capping Jurassic (c. $182 \mathrm{Ma}$ ) flood basalts indicates an extended hiatus after the deposition of the Soutpansberg rocks. This may explain why so few Soutpansberg-aged lavas have been recognised and emphasises the importance of studying their preserved feeder intrusions. The Zimbabwe block is not covered by a similarly complete stratigraphy as the Kaapvaal block yet still preserves a rather extensive Mashonaland dolerite sill complex (Fig. 1(B)). For further details regarding the geology of the Kalahari Craton, as well as the strata covering primarily the Kaapvaal block we refer to other publications (e.g., Johnson et al. 2006, and references therein).

\subsection{The assembly of the proto-Kalahari Craton}

The proto-Kalahari Craton was assembled during the course of several tectonic and magmatic events. Fig. 1(A) shows the outline of the proto-Kalahari Craton at $c .1 .75 \mathrm{Ga}$, when the craton consisted of a nucleus of Archaean-Palaeoproterozoic constituents of the Zimbabwe, Kaapvaal and Grunehogna cratons. The western flank includes Proterozoic units produced during prolonged crustal accretion at $c$. 2.00-1.75 Ga during the Magondi and Okwa-Kheis orogenies (Jacobs et al. 2008, and references therein). The Kaapvaal and Zimbabwe cratons are joined together along the Limpopo Mobile Belt, which consists of the Northern Marginal, Central and Southern Marginal zones (NMZ, CZ and SMZ, respectively), separated from each other by major shear zones (e.g. Kramers et al. 2006). It is commonly believed that the SMZ and NMZ represent the deep crustal level equivalents to the Kaapvaal and Zimbabwe granitoid-greenstone terrains respectively, whereas the $\mathrm{CZ}$ is structurally and lithologically different from the other two terrains. The Central Zone is polymetamorphic, having experienced a late Archaean ( $c$. 2.69-2.56 Ga) and a Palaeoproterozoic (c. 2.04-2.00 Ga) event (e.g. Kramers et al. 2006; Rigby et al. 2011). Researchers have debated the significance of these different tectonic, metamorphic and magmatic events, some arguing for an Archaean-only collision between Kaapvaal and Zimbabwe (e.g. Roering et al. 1992; Ranganai et al. 2002), whereas others point towards the importance of a possible Palaeoproterozoic event at c. 2.0 Ga amalgamating the two cratons (e.g. Holzer et al. 1998; Bleeker 2003; Söderlund et al. 2010). Rigby et al. (2011) proposed a tectonic model where Limpopo's CZ first collided with a SMZ-Kaapvaal block during the Neoarchaean, after which this composite Kaapvaal-CZ entity docked with a NMZ-Zimbabwe block in the Palaeoproterozoic, completing the proto-Kalahari formation. Following Bleeker's (2004) methodology of comparing magmatic "barcodes", Söderlund et al. (2010) found that mafic events on the Zimbabwe and Kaapvaal cratons support such a post-2.0 Ga amalgamation between these two crustal blocks. This concept is investigated further by Alebouyeh et al. (this volume).

\subsection{The Magondi and Okwa-Kheis belts}

The tectonic history of the western margin of the proto-Kalahari Craton, with the Magondi Belt in Zimbabwe and the OkwaKheis Belt in South Africa and Namibia (Fig. 1(A)), is still poorly understood (partly due to an extensive Kalahari Desert cover). The Magondi Supergroup is found on the north-western margin of the Zimbabwe Craton (Fig. 1(B)) and was created by the deposition of clastic sediments and extrusion of basaltic and 
felsic lavas that probably are c. 2.2-2.0 Ga, followed by deformation and metamorphism along the Magondi Belt at c. 2.001.97 Ga (e.g., Master et al. 2010). The Magondi Belt has been correlated with 2055-2057 Ma orthogneisses and meta-rhyolites of the Okwa Basement farther to the south-west (Ramokate et al. 2000; Mapeo et al. 2006).

The Kheis Province with its north-south structural fabric (Stowe 1986) crops out on the western flank of the Kaapvaal Craton (Fig. 1(A)) and is composed of metavolcanic rocks, quartzites and reworked crustal basement (Moen 1999) with unconstrained depositional and metamorphic ages. It has been interpreted as a thin-skinned thrust belt (Stowe 1986). Despite the lack of robust geochronology, rocks of Kheisian origin have nonetheless been correlated with a continuous Magondi Belt (Hartnady et al. 1985; Master 1994; Jacobs et al. 2008). However, the Kheisian tectonic fabric is younger than the Magondi Belt, as U-Pb SHRIMP dating of a deformed rhyolite within the Kheis supracrustal succession and the intrusive Kalkwerf Gneiss yields ages of c. $1.3 \mathrm{Ga}$ (Moen \& Armstrong 2008), leading these authors to argue that there is no evidence for a $c .1 .8 \mathrm{Ga}$ orogeny in the Kheis Province, and that it instead forms part of the Mesoproterozoic Namaqua Province. To the west of the Kheis Province lies the Rehoboth Province (Fig. 1(A)), which consists of Palaeo- to Mesoproterozoic volcano-sedimentary as well as intrusive rocks (e.g. Van Schijndel et al. 2011 and references therein). A recent zircon provenance study on the Billstein Quartzite in the Rehoboth Province yielded three age populations recording three episodes of crustal development at c. 2.982.7 Ga, $c .2 .2-1.9 \mathrm{Ga}$ (with a peak at $c .1 .87 \mathrm{Ga}$ ) and finally at $c$. 1.32-1.05 Ga. Furthermore, mafic volcanic rocks and amphibole schist of the Elim Formation have yielded an unpublished $\mathrm{U}-\mathrm{Pb}$ LA-ICPMS age of $1863 \pm 10$ Ma (Van Schijndel et al. 2011).

\subsection{The Waterberg and Soutpansberg Groups}

The predominately sedimentary Waterberg Group was deposited across a larger area of northern Kaapvaal, whereas rocks of the Soutpansberg Group are restricted to the Soutpansberg Basin within the SMZ of the Limpopo Mobile Belt (Fig. 1(A, B)). The main Waterberg Basin is bounded by the Melinda fault zone and the Thabazimbi-Murchison lineament along its northern and southern borders, respectively, whereas the subsidiary Middelburg Basin overlies the Bushveld Complex (Barker et al. 2006). There has been considerable debate regarding the age relationships between the Waterberg and the Soutpansberg basins, but detailed mapping in the Blouberg area by Bumby et al. (2002) shows that the Mogalakwena Formation of Waterberg age is unconformably overlain by the Wyllie's Poort Formation of Soutpansberg origin. The age of the Waterberg Group is bracketed by U-Pb SHRIMP zircon ages of 2058-2043 Ma on quartz porphyry lavas near its base (Dorland et al. 2006) and 1879$1872 \mathrm{Ma}$ U-Pb TIMS baddeleyite ages on dolerite sills (Hanson et al. 2004a). Hence sedimentation in the Waterberg basin ( $c$. 2058 to $>1879 \mathrm{Ma}$ ) was partly coeval with Bushveld magmatism and compression/transpression within the Limpopo Belt, and the subsidence of the Middelburg Basin can be inferred to be controlled to a large degree by thermal subsidence coupled with the cooling of the giant Bushveld intrusion (Barker et al. 2006).

The Soutpansberg stratigraphy consists of quartzites, conglomerates, greywackes and shales divided into four formations (Tshifhefhe, Funduzi, Wyllie's Poort and Nzhelele Formations).
The Funduzi and Wyllie's Poort Formation contain minor basalts and pyroclastic rocks intercalated with these sedimentary rocks. The Soutpansberg stratigraphy also consists of two distinctive formations of basaltic lava flows, namely the lowermost 3-km-thick Sibasa and the uppermost 400-m-thick Musekwa formations (Barker et al. 2006). Lower Soutpansberg strata unconformably overlie the $2021 \pm 5$ Ma Entabeni Granite (Dorland et al. 2006) and the Sibasa Formation itself was loosely constrained by a Rb-Sr whole-rock age of $1769 \pm 34 \mathrm{Ma}$ (Barton 1979) probably reflecting the timing of alteration of these basalts (Barker et al. 2006). The 1879-1872 Ma post-Waterberg dolerite sills have previously been interpreted as feeders to the basaltic flows of the Sibasa Formation (Hanson et al. 2004a) and ENE-trending dykes cutting the Blouberg Formation and Waterberg strata reported by Bumby et al. (2001) may also have fed the thick basaltic lavas. Importantly the Wyllie's Poort Formation carries detrital zircons of $c .1 .85$ Ga age (Dorland 2004) defining a maximum age for the deposition of the upper Soutpansberg stratigraphy. This age is consistent with two $c$. $1.83 \mathrm{Ga}$ U-Pb zircon ages for lenticular pyroclastic units, inter-bedded with basaltic lavas and clastic sediments in the uppermost part of the formation (Geng et al. 2014), providing the currently most precise termination age for Sibasa volcanism.

The tectonic setting of the Soutpansberg Basin has been discussed by several workers. A model involving an aulacogen extending inwards from the eastern corner of the craton was presented by Jansen (1975), but this was discarded by Barker (1976) who pointed out the non-supportive palaeocurrent directions and invoked a rifted or "yoked" basin as a more realistic setting. Meinster (1977) and Cheney et al. (1990) both proposed that the Soutpansberg sediments are the structural-erosional remnants of a much larger basin, at odds with a rift-related environment operating at that time. This idea is supported by Watkeys (1984), who observed rocks of Soutpansberg origin within the Tuli trough in the Limpopo Mobile Belt. Combining the two different models, Barker et al. (2006) proposed that the lowermost units of the basin (sub-Wyllie's Poort Formation) were produced within a syn-rift environment, whereas the rest of the stratigraphy was deposited in a broader post-rift related basin. Furthermore, Bumby et al. (2002) suggested that the Soutpansberg strata were laid down in a half-graben following the orogenic collapse of the Limpopo Mountains.

\subsection{Dolerite intrusions across the Zimbabwe and Kaapvaal Cratons}

Several cross cutting dyke swarms are particularly well exposed within Zimbabwe's granitoid basement, including the prominent N-trending 2.575 Ga Great Dyke of Zimbabwe and its satellite intrusions, WNW-NNW-trending c. 2.51-2.41 Ga Sebanga dykes, and possibly other undated pre- to syn-Bushveld swarms (Stubbs 2000; Söderlund et al. 2010). It is only the c. $1.87 \mathrm{Ga}$ Mashonaland sills and younger Umkondo and Karoo intrusions (Stubbs et al. 1999), that correlate to coeval intrusions across the Kaapvaal Craton, leading Söderlund et al. (2010) to favour the $c$. $2 \mathrm{Ga}$ amalgamation of these two cratons during the formation of the Limpopo Belt's CZ (Fig. 1(A, B)).

There are also several different dyke swarms across the exposed northern to eastern parts of the Kaapvaal Craton (Fig. 1(B, C)). In chronological order, the oldest of these is a SE-trending and c. 2.9 Ga feeder swarm to Pongola Supergroup lavas (Olsson et al. 2010; Gumsley et al. 2013, 2015) that cuts across the exposed south-eastern part of the Kaapvaal Craton. A 
swarm of c. $2.7 \mathrm{Ga}$ feeder dykes to lava formations within the Ventersdorp Supergroup and the Transvaal Supergroup's basal ("protobasinal"; Eriksson et al. 2001) lavas appear to be radiating from a centre that is currently located beneath the eastern lobe of the Bushveld Complex (Olsson et al. 2011). These dykes are recognised by Gumsley et al. (this volume) to be part of at least three successive magmatic events during a c. 40-Myr-long period, between $c$. 2.70 and $2.66 \mathrm{Ga}$. After the emplacement of the $2.06 \mathrm{Ga}$ Bushveld Complex (so far uncorrelated to any significant feeder dyke swarm), there was the emplacement of the $c .1 .93 \mathrm{Ga}$ Tsineng dyke swarm (Alebouyeh et al. this volume), closely followed by the NE-trending BHDS, which cuts the predominately sedimentary 2660-2060 Ma Transvaal Basin (Eriksson et al. 2001), the 2058-2054 Ma Rustenburg layered sequence of the Bushveld Complex (Scoates \& Friedman 2008; Olsson et al. 2010) and the 2060 Ma Phalaborwa Complex (Reischmann 1995; Heaman \& LeCheminant 1993).

After the emplacement of the BHDS, (1) smaller dyke swarms related to various $c .1 .43-1.14 \mathrm{Ga}$ alkaline centres were emplaced across the central parts of the Kaapvaal Craton (Verwoerd 2006), (2) even younger generations of c. 1.1 Ga Umkondo intrusions (Hanson et al. 2004b) may radiate as several sub-swarms from igneous centres along the margins of the Kalahari Craton (de Kock et al. 2014), and (3) an extensive array of c. $0.18 \mathrm{Ga}$ Karoo dyke swarms and sill complexes (Jourdan et al. 2006; Svensen et al. 2012) were emplaced during the breakup of the southern part of the Gondwana supercontinent.

\section{Dolerite dyke targets and U-Pb TIMS age results}

Dolerite dykes were targeted from geological and geophysical maps, coupled with satellite images from Google Earth ${ }^{\mathrm{TM}}$. Sample locations are given in longitude (long.) and latitude (lat.) next to each sample description, below, as well as plotted in Fig. 1(C). Uranium-lead ( $\mathrm{U}-\mathrm{Pb})$ isotope data are provided in Table 1 (Appendix B).

Samples for geochronology were prepared by careful crushing and differential flotation of baddelyite crystals on a Wilfey Table, following the protocol by Söderlund and Johansson (2002). A majority of the extracted baddelyite crystals were small (30-60 $\mu \mathrm{m}$ in their longest dimension). Transparent and blade-like baddeleyite crystals (or fragments thereof) without any visible rims of polycrystalline zircon were preferentially picked for $\mathrm{U}-\mathrm{Pb}$ dating. Analyses were performed at the Laboratory of Isotope Geology (LIG) at the Museum of Natural History in Stockholm (Sweden) and at the Jack Satterly Geochronology Laboratory (JSGL) at the University of Toronto in Canada, as specified in Table 1. The reader is referred to Appendix A for detailed description of analytical methods used at these laboratories. A concordia diagram for each of eleven dated samples is displayed in Fig. 2, with error ellipses reported at a 95\% confidence level. Decay constant errors for ${ }^{238} \mathrm{U}$ and ${ }^{235} \mathrm{U}$ are ignored in their calculated age uncertainties.

\subsection{Dykes in the north-eastern Kaapvaal Craton}

The following eight dykes are all found in the north-eastern Kaapvaal Craton (Fig. 1(C)), where they cut Palaeo- and Mesoarchaean gneisses (e.g. Robb et al. 2006), the c. $2.9 \mathrm{Ga}$
Murchison Greenstone Belt (e.g. Brandl et al. 2006), various granitoid plutons of Meso- to Neoarchaean age and the $2060 \mathrm{Ma}$ alkaline Phalaborwa Complex (Reischmann 1995).

BCD1-12 (long. 30.79738 E; lat. $24.40592 \mathrm{~S}$ ) was sampled along road R527, approximately $17 \mathrm{~km}$ south-west of the town Hoedspruit where it intrudes rocks of the Makhutswi Gneiss, dated at $3228 \pm 12 \mathrm{Ma}$ and $3063 \pm 12 \mathrm{Ma}$ (Poujol et al. 1996; Poujol \& Robb 1999). Sample BCD1-12 was characterised in terms of its geochemistry and petrology by Klausen et al. (2010) and together with seven other sites was used to calculate a palaeopole for the Black Hills swarm by Lubnina et al. (2010). It is difficult to trace this dyke from Google Earth ${ }^{\mathrm{TM}}$ or find its contacts with the surrounding country rocks, and Lubnina et al. (2010) therefore noted the unit as a possible sill. However, the sample location coincides with a mapped $057^{\circ}$-trending dyke on a geological map and we tentatively use this orientation. Analyses of four multi-grain fractions, each consisting of between 3 and 11 baddeleyite grains, together with one single-grain fraction, give a spread of linearly discordant data (1.7-8.8\%). Regression of all five data points yields an upper intercept of $1850.1 \pm 6.8 \mathrm{Ma}$, interpreted as the emplacement age of the dyke, and a lower intercept at $160 \pm 150$ Ma. Mean Square of Weighted Deviates $(\mathrm{MSWD})=1.7($ Fig. 2(A))

BCD1-18 (long. 30.47125 E; lat. $24.27669 \mathrm{~S}$ ) was collected from a $047^{\circ}$-trending dyke (traced from Google Earth ${ }^{\mathrm{TM}}$ ) at a road-cut in the northern edge of the town Makgaung, where it intrudes the $3091 \pm 5$ Ma Harmony Granite (Poujol \& Robb 1999). Analyses for BCD1-18 included three fractions with 2 to 4 baddeleyite grains each. All fractions are clustered and moderately discordant (1.8-2.2\%), showing a high degree of overlap, and have ${ }^{207} \mathrm{~Pb} /{ }^{206} \mathrm{~Pb}$ ages that range between 1848.5 and $1852.1 \mathrm{Ma}$ (Table 1, Fig. 2(B)). An unconstrained regression through the three clustered fractions generates a poorly constrained age of $1853 \pm 32 \mathrm{Ma}$ with a lower intercept at $318 \pm 2000 \mathrm{Ma}$ (MSWD $=0.25)$. Using a forced lower intercept through $0 \pm 200 \mathrm{Ma}$ yields an upper intercept age of $1848.6 \pm 2.9 \mathrm{Ma}$ (MSWD =0.16), which is interpreted as the crystallisation age.

BCD1-21 (long. 30.56809 E; lat. 24.34537 S) comes from a cut along the same road as BCD1-18 but $\sim 12.5 \mathrm{~km}$ to the south-east, where the Harmony Granite and a coinciding $012^{\circ}$-trending dyke is easily traced from Google Earth ${ }^{\mathrm{TM}}$. Analysed $\mathrm{U}-\mathrm{Pb}$ fractions comprise between 2 and 4 baddeleyite crystals each. Regression of three normally discordant analyses $(\mathrm{A}, \mathrm{B}, \mathrm{D} ; 1.2-2.2 \%)$ and one reversely discordant fraction $(\mathrm{C}$; $-3.0 \%$ ) yields an upper intercept of $1870.1 \pm 4.4 \mathrm{Ma}$, with a negative lower intercept at $-193 \pm 570 \mathrm{Ma}(\mathrm{MSWD}=0.27)$. An anchored lower intercept at $0( \pm 200)$ Ma gives a nearly identical upper intercept age of $1870.7 \pm 4.4 \mathrm{Ma}$ with a MSWD value of 0.35 (Fig. 2(C)), interpreted as the emplacement age.

BCD5-25/29 (long. 30.65823/30.71606 E; lat. 23.77793/23.65198 $S$ ) was collected from the largest and most prominent dyke of the swarm that can be followed for nearly $25 \mathrm{~km}$ along strike. The dyke is slightly irregular but generally follows an average $028^{\circ}$-trend. It cuts across the Mesoarchaean Groot-Letaba Gneiss and the Murchison Greenstone Belt (e.g. Robb et al. 2006). The dyke was sampled at two localities, BCD5-25 in the southern end and BCD5-29 in its northern end. Three fractions comprising 2 to 4 crystals each of the combined BCD5-25/29 samples analysed at JSGL are nearly concordant (0.3-1.7\% discordance), while one fraction (containing 6 crystals) analysed at LIG is $3.2 \%$ discordant (Table 1, Fig. 2(D)). A free regression through 
all four analyses gives an upper intercept of $1859.1 \pm 3.1$ Ma with a negative lower intercept of $-373 \pm 520 \mathrm{Ma}(\mathrm{MSWD}=0.61)$. Forcing the lower intercept through $0 \pm 200$ Ma yields an upper intercept age of $1860.9 \pm 2.7 \mathrm{Ma}$, with an MSWD value of 1.2. This emplacement age is within error of the ${ }^{207} \mathrm{~Pb} /{ }^{206} \mathrm{~Pb}$ age of the least discordant JSGL fraction C (1858.8 $\pm 4.1 \mathrm{Ma})$.

BCD5-28 (long. 30.73052 E; lat. 23.65573 S) was collected from a ridge outcrop $\sim 1.5 \mathrm{~km}$ to the east of BCD5-25/29 within the Groot-Letaba Gneiss. The locally measured $054^{\circ}$-trend is somewhat speculative however, since it is difficult to trace from Google Earth ${ }^{\mathrm{TM}}$. Four fractions, comprising 4 to 6 baddeleyite crystals each, plot moderately discordant (3.7-8.2\%) that collectively define a chord yielding an upper intercept of $1862.3 \pm 6.5 \mathrm{Ma}$ (Table 1, Fig. 2(E)), and a lower intercept at $200 \pm 160 \mathrm{Ma}(\mathrm{MSWD}=0.62)$. The upper intercept age is regarded as the crystallisation age of the mafic dyke.

BCD5-78 (long. 30.83629 E; lat. 24.20702 S) was taken from a road-cut approximately $30 \mathrm{~km}$ south-west of Phalaborwa where a somewhat discernible $046^{\circ}$-trending dyke intrudes both the Makhutswi Gneiss and the Harmony Granite. Analyses of four fractions of baddeleyite, consisting of between 2 and 10 grains each, are slightly discordant $(1.6-3.8 \%)$, but have ${ }^{207} \mathrm{~Pb} /{ }^{206} \mathrm{~Pb}$ dates in a narrow range between 1845.7 and $1848.6 \mathrm{Ma}$ (Table 1, Fig. 2(F)). Free regression of all four fractions yields an upper intercept of $1846.7 \pm 8.1 \mathrm{Ma}$ with a poorly constrained lower intercept at $-61 \pm 410 \mathrm{Ma}$. Anchoring the lower intercept at $0 \pm 200 \mathrm{Ma}$ yields an upper intercept of $1847.9 \pm 4.5 \mathrm{Ma}(\mathrm{MSWD}=0.57)$, regarded as the best age estimate of emplacement

$B C D 8-13$ and -14 are both Foskor drill core samples from north-east-trending dykes intruding the $c .2060$ Ma Phalaborwa Complex (Reischmann 1995; Heaman \& LeCheminant 1993). BCD8-13 was taken from a well mapped $053^{\circ}$-trending dyke in the northern margin of the southernmost pit. An unforced linear regression through all six variably discordant analyses $(0.6-4.1 \%)$ gives an upper intercept age of $1839.4 \pm 4.1 \mathrm{Ma}$ (lower intercept age at $480 \pm 260 \mathrm{Ma}$ ) with an MSWD value of 2.2 (Table 1, Fig. 2(G)). The relatively higher MSWD value reflects the slight scattering of fraction $\mathrm{A}$, which may be analytical or due to a more complex secondary $\mathrm{Pb}$-loss history. Exclusion of fraction A from the age regression results in an improved fit $(\mathrm{MSWD}=0.12)$, but an identical upper intercept age of $1838.7 \pm 3.9 \mathrm{Ma}$. The $1839.4 \pm 4.1 \mathrm{Ma}$ age is favoured as the crystallisation age of the dyke.

Sample BCD8-14 was collected from another well mapped $047^{\circ}$-trending dyke in the southern part of the Palabora mine pit. Four discordant fractions (1.6-3.9\%), comprising 2 to 5 baddeleyite grains each, fall along a chord defining an upper intercept emplacement of $1851.8 \pm 4.9 \mathrm{Ma}$ and a lower intercept at $340 \pm 170 \mathrm{Ma}(\mathrm{MSWD}=1.3$, Fig. $2(\mathrm{H}))$.

\subsection{More northerly trending dykes farther to the south}

Whereas the Archaean terrain to the north-east is dominated by a conjugate set of both NE- and NNE-trending dykes (apparent on geological maps and Google Earth ${ }^{\mathrm{TM}}$, as well as in Fig. 1(C)), the Transvaal Basin appears to be cut almost exclusively by NNE-N-trending dykes. Thus, there appears to be a progressive, possibly "dog-legged" (Uken \& Watkeys 1997), shift from NEtrends to NNE- and N-trends towards the south and west from the Archaean terrain (Fig. 1(B)). Klausen et al. (2010) tentatively attributed this to an artefact of the Transvaal cover filtering out more north-easterly trending c. $2.7 \mathrm{Ga}$ dykes, and thereby exposing only a more prominent northerly trending younger BHDS. As already indicated by NE-trending Black Hills dykes presented above, however, this does not seem to be the case and these observations will be addressed in more detail below.

BCD5-85 (long. 30.75788 E; 24.90711 S) was collected in the vicinity of Pilgrim's Rest, where a $020^{\circ}$-trending dyke intrudes the Transvaal Supergroup's Malmani Dolomite Formation. Baddeleyite recovery from sample BCD5-85 was very low. One single-grain analysis (fraction A) is nearly concordant $(0.3 \%$ discordant $)$, while fraction $\mathrm{B}$ containing 3 grains is moderately discordant $(1.5 \%)$. Both fractions have similar ${ }^{207} \mathrm{~Pb} /{ }^{206} \mathrm{~Pb}$ ages, at 1855.4 and $1857.5 \mathrm{Ma}$ (Table 1, Fig. 2(I)). A simple linear regression of the two data points yields an upper intercept of $1858 \pm 14 \mathrm{Ma}$, with an imprecise lower intercept at $277 \pm 2700 \mathrm{Ma}$. A similar, but more precise, estimate of the timing of dyke crystallisation is provided by the weighted average ${ }^{207} \mathrm{~Pb} /{ }^{206} \mathrm{~Pb}$ age, at $1857 \pm 8.9 \mathrm{Ma}$ (probability of fit $=0.85$ and MSWD $=0.04)$.

BCD6-05 (long. 30.48782 E; lat. $25.99445 \mathrm{~S}$ ) was sampled from a $004^{\circ}$-trending dolerite dyke $>200 \mathrm{~km}$ to the south of the main Black Hills swarm, within an area dominated by $2.95 \mathrm{Ga}$ and 2.70 Ga dyke generations (Olsson et al. 2010, 2011). This dyke intrudes both the Archaean granitoid-greenstone terrain and overlying Transvaal Supergroup cover rocks. Analyses for five fractions (containing 1 to 3 baddeleyite grains each) have a relatively high proportion of common $\mathrm{Pb}$ and large associated errors, though the data fall near Concordia (Table 1, Fig. 2(J). Free linear regression yields a poorly constrained upper intercept age of $1857 \pm 16 \mathrm{Ma}$ and a lower intercept at $525 \pm 960 \mathrm{Ma}$ $(\mathrm{MSWD}=0.68)$. A forced regression through $0 \pm 200 \mathrm{Ma}$ yields $1851.8 \pm 7.3 \mathrm{Ma}(\mathrm{MSWD}=0.70)$, and is the preferred age of crystallisation of this dyke.

$B C D 8-12$ was collected from a drill core provided by NKWE Platinum, where a $017^{\circ}$-trending dyke has intruded Critical Zone rocks of the Bushveld Complex. Four fractions were analysed, comprising between 2 and 5 baddeleyite grains each. Data cluster on or near Concordia (Table 1, Fig. 2(K)). Free regression of two reversely discordant fractions $(-1.8$ and $-1.9 \%)$ and two slightly discordant fractions $(0.6 \%$ and $1.1 \%)$, produces an upper intercept age of $1841.9 \pm 3.5 \mathrm{Ma}$ with a negative lower intercept at $-1111 \pm 1800 \mathrm{Ma}$. If the lower intercept is forced through the origin, the upper intercept for this regression is $1844.4 \pm 2.6 \mathrm{Ma}$, with an MSWD value of 1.7 , which is regarded as the best estimate of dyke emplacement.

\subsection{Ages related to dyke distributions and trends}

Some of the dykes record lower intercept ages that are suspiciously similar to the emplacement age of the c. $180 \mathrm{Ma}$ Karoo LIP (Jourdan et al. 2005) - a widespread magmatic event across this part of the Kaapvaal Craton (Cox 1988) - whereas others produce unrealistically negative lower intercepts when free regressions are conducted. Lubnina et al. (2010) also recorded a thermochemical overprint in their palaeomagnetic dyke results that could be related to this Karoo LIP event. No detailed petrography was performed on the sampled dolerites, but the baddeleyite morphologies revealed rims of suspected polycrystalline zircon which could form during such a thermal event when silica-rich fluids percolate through the crust (Davidson \& van Breemen 1988). Therefore, we choose to force some 


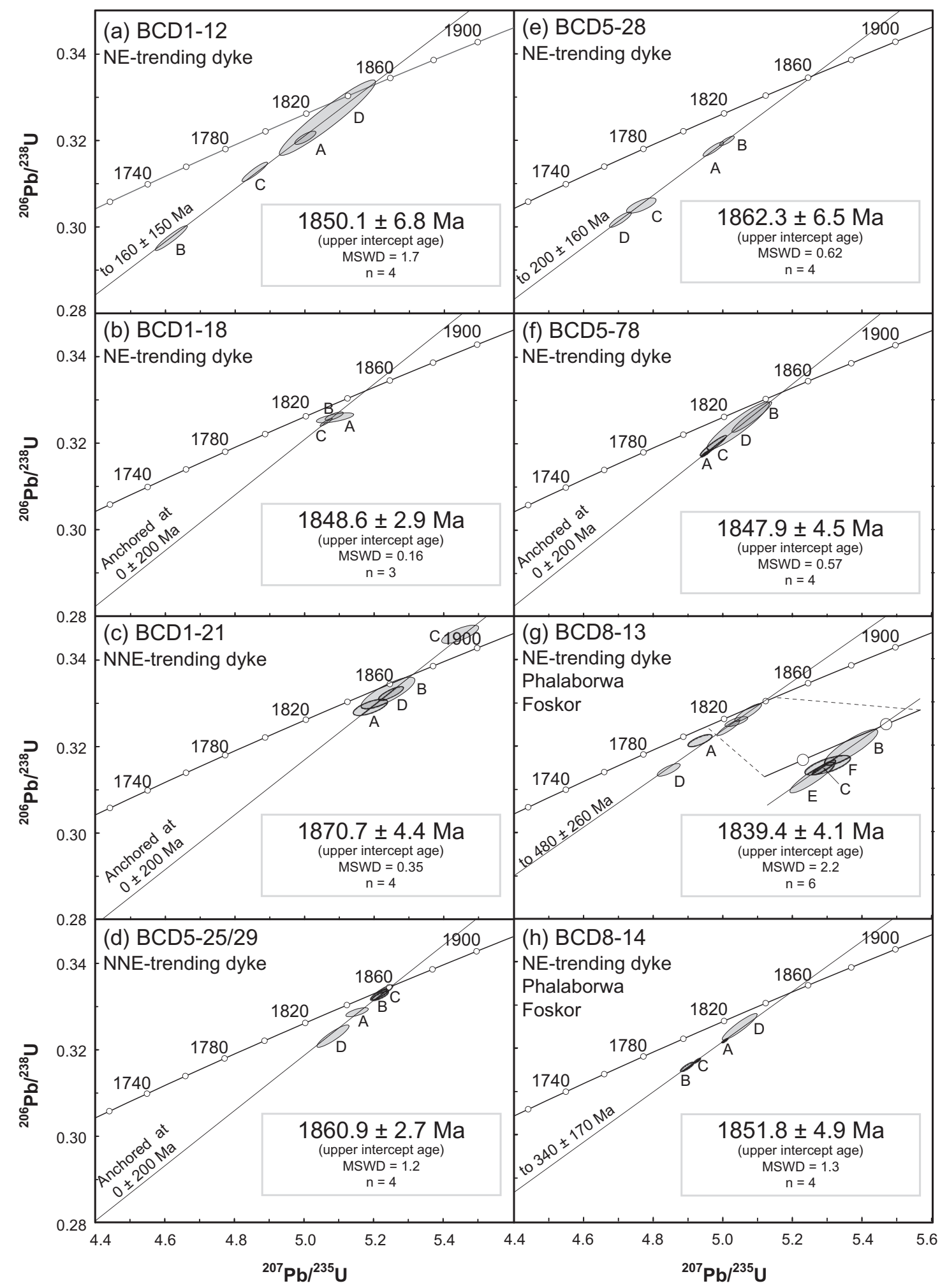

Fig. 2. Concordia diagrams of eleven dykes belonging to the c. 1875-1835 Ma BHDS. The algorithms of Ludwig (2003) were used in the age calculations and concordia error ellipses are shown at $95 \%$ confidence levels. ${ }^{235} \mathrm{U}$ and ${ }^{238} \mathrm{U}$ decay constant errors are not included in the reported U-Pb ages. MSWD = Mean Square of Weighted Deviates.

of the age regressions through a lower intercept of $0 \pm 200 \mathrm{Ma}$ to encompass both present-day lead loss and isotopic disturbance that may have been triggered by hydrothermal activity during the Karoo LIP event.
The age data presented here indicate a long-lived magmatic event. The age range of the 11 dated Black Hills dykes, from the oldest BCD1-21 $(1870.7 \pm 4.4 \mathrm{Ma})$ to the youngest BCD8-13 $(1839.4 \pm 4.1 \mathrm{Ma})$ samples, document a magmatic event that last- 


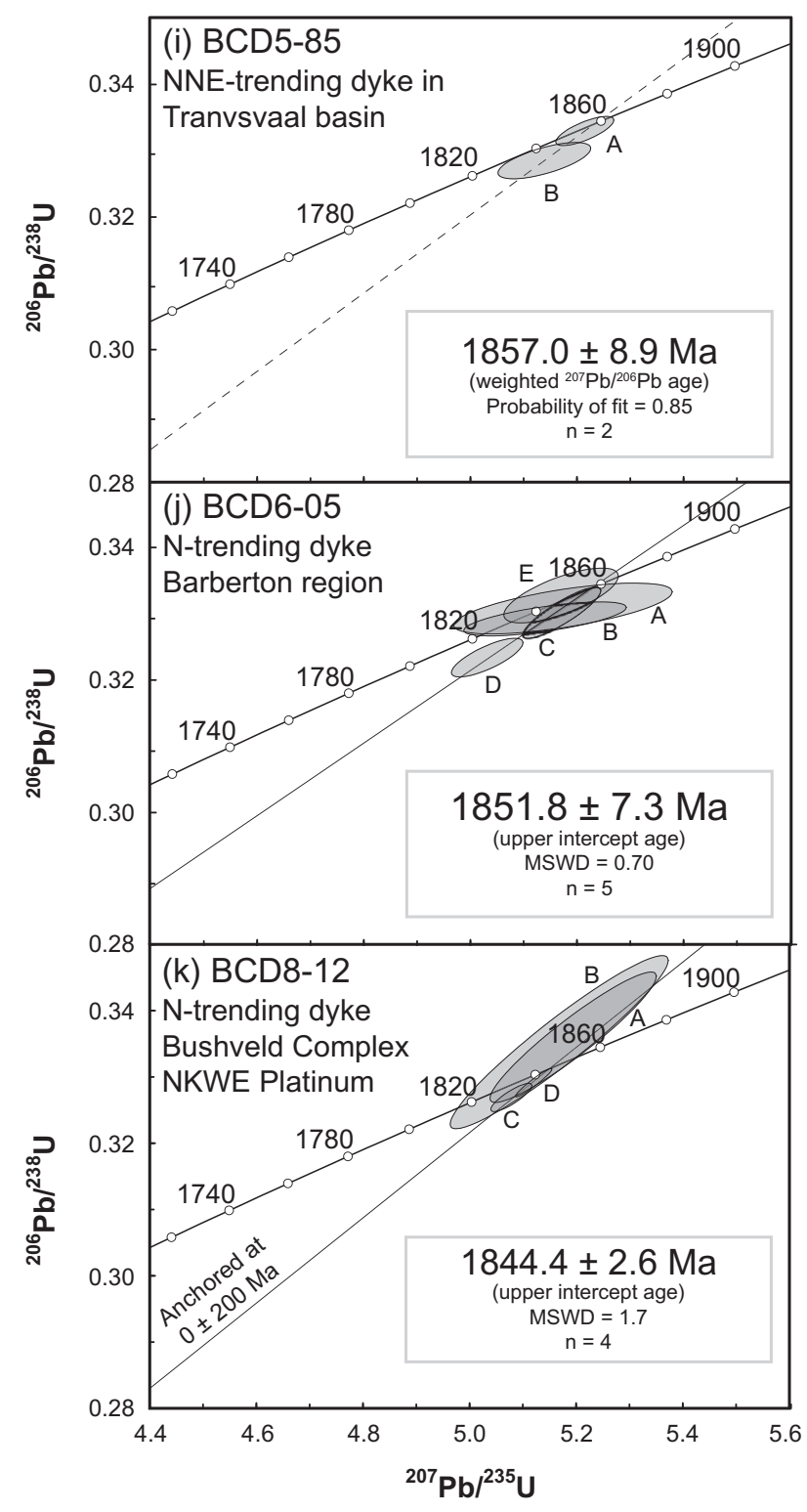

Fig. 2. Continued.

ed at least 30 Myrs (nearly 40 Myrs between 1875 and $1835 \mathrm{Ma}$, when upper and lower U-Pb age-errors are considered). A probability frequency distribution analysis on this statistically small data-set of only 11 ages reveals a weak bimodal clustering, with peaks at approximately late $1840 \mathrm{Ma}$ and early $1860 \mathrm{Ma}$ (top of Fig. 3), which could indicate that we are dealing with two subswarms within the BHDS. BCD8-14 and its neighbouring, yet $\sim 20 \mathrm{Myr}$ younger, BCD8-13 dyke in the Phalaborwa Complex provide the best example of extended gaps between dyke emplacements within any given part of the BHDS.

The cumulative along-strike distribution of the BHDS ranges from at least the Limpopo Mobile Belt in the north to the Barberton Greenstone Belt in the south - a distance of $\sim 300 \mathrm{~km}-$ whereas the most westerly sampled BCD8-12 dyke and the most easterly sampled Phalaborwa dykes (BCD8-13 and -14) indicate that the swarm has a minimum width of $\sim 75 \mathrm{~km}$. As indicated by roughly coeval sills and lavas across much of the proto-Kalahari Craton, the swarm is probably more extensive than that.
A simple histogram on the side of Figure 3(A) clearly separates the statistically small set of trend estimates for the BHDS into a more NE- and more NNE-trending sub-swarm. This bimodal distribution resembles the previously mentioned observation in Google Earth ${ }^{\mathrm{TM}}$ of a similar conjugate dyke swarm pattern across the north-eastern corner of the exposed Archaean basement of the Kaapvaal Craton. The fact that as many as six of the dated dykes trend NE, invalidates past presumptions that NE-trending c. 2.70-2.66 Ga dykes (Olsson et al. 2011; Gumsley et al. this volume) are distinguishable from a more NNE-trending c. 1.87-1.84 Ga BHDS purely on the basis of different trends. Amongst our 11 dated dykes, we note that the NNE-trending BCD1-21 in the area south of the Murchison Greenstone Belt (Fig. 1(B, C)) is 30-18 Myrs older than nearby NE-trending dykes (BCD1-12, BCD1-18, BCD5-78 and BCD8-13 and -14). An interpretation where early NE-trending dykes were superseded by younger NNE-trending dykes is, however, not favoured by both a coeval NNE-trending BCD5-25/29 and a NE-trending BCD5-28 to the north of the Murchison Greenstone Belt, even if this comparison suffers from a less well-constrained age of BCD5-28 $( \pm 6.5 \mathrm{Ma})$, as well as from its uncertain trend. The NNE-trending dyke BCD5-85 in the Transvaal basin, as well as the more N-trending BCD6-05 far to the south, both exhibit large age uncertainties preventing temporal discrimination. Sample BCD8-12 does show that NNE-trending dykes across the Bushveld Complex are at least partly coeval with NE-trending dykes in the Archaean terrain. Thus, it might be that the BHDS is overall more randomly trending when cutting across the north-eastern part of the Kaapvaal Craton, partly following a pre-existing more NE-trending c. 2.7 Ga swarm (as Uken \& Watkeys 1997 suggested for their Karoo dykes) and becomes more consistently NNE-trending when cutting through overlying cover rocks.

\section{Geochemistry of the BHDS}

As described more explicitly in Appendix A, geochemical compositions of each of the 11 dated dykes were determined on representative, fresh and clean bulk rock samples, processed and analysed for major and trace elements at two different laboratories. Bulk rock geochemical data on all 11 dated dykes, and one Mashonaland dolerite sill dated by Söderlund et al. (2010) are provided in Table 2 (Appendix C).

\section{1. $\mathrm{MgO}$ versus age}

$\mathrm{MgO}$ content of dykes may be used as an index of differentiation due to fractional crystallisation within basaltic magmas, and thereby discriminated between dykes of more or less evolved composition. The ages of the dykes in this study plotted against their $\mathrm{MgO}$ concentrations (Fig. 3(B)) reveal a rough correlation between the statistically recognised older sub-swarm of four more "primitive" dykes (MgO = 9.4-6.8 wt\%; BCD5-25/29, BCD121, BCD5-28 and BCD5-85) and a younger sub-swarm of seven more "evolved" dykes (MgO = 5.6-4.2 wt\%; BCD1-12, BCD118, BCD5-78, BCD6-05, BCD8-12, BCD8-13 and BCD8-14). Even if an increased degree of differentiation is expected with time, it is unlikely that these samples were petrogenetically related because of the overall long duration with statistical age-peaks for the two sub-swarms separated by $>10$ Myrs. Alternatively, earlier dykes may have been fed more directly from their source 


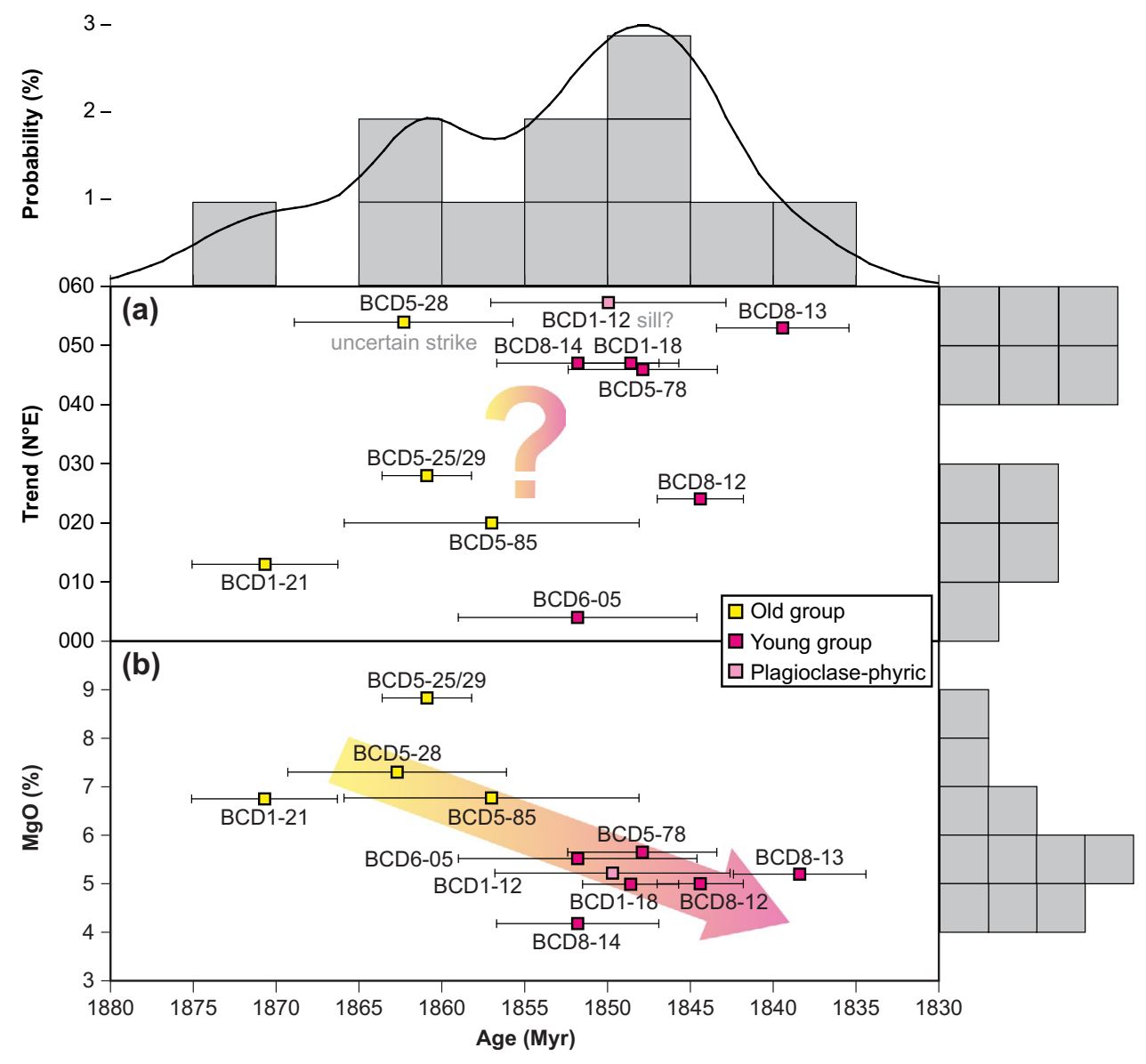

Fig. 3. Summary of obtained age data (Table 1) of the BHDS with errors reported at the $95 \%$ confidence level, plotted against A. sampled dykes' trends and $\mathbf{B}$. MgO (Table 2). Data symbols are coloured according to two age sub-groups of older (yellow) and younger (magenta) dykes (including one pink symbol indicating a plagioclase-phyric young dyke/sill).

whereas magmas differentiated longer in established crustal magma chambers during the latter intrusive phase. Regardless, further geochemical interpretations can now be addressed within this new context of an older "primitive" versus a younger "evolved" sub-swarm within the BHDS.

\subsection{Classification}

All eleven dated BHDS samples are typical sub-alkaline tholeiitic basalts (Fig. 4). Pristine igneous weathering index values, calculated according to Ohta and Arai (2007), are not shown but verify that alkalis have not been remobilised by weathering or other alteration processes. Thus, any differentiation trend expressed by increasing alkalis is related to fractional crystallisation and/or assimilation, even if these rise against constant to slightly decreasing $\mathrm{SiO}_{2}$ (Fig. 4(A)), typical for early differentiation within tholeiitic basaltic suites (Fig. 4(B)), before FeTi-oxide fractionation sets in. This pristine chemical signature is supported by a generally fresh appearance in the field and hand specimens, as well as thin sections of other NE-trending dykes from the area (Mkhize 2008; Klausen et al. 2010).

Though NE-trending dykes across the Kaapvaal Craton (potentially including c. $2.7 \mathrm{Ga}$ dykes) display significant scatter when all published data are compared (Fig. 4(B)), one is struck by the very linear $\mathrm{MgO}$-depletion and $\mathrm{FeO}_{\mathrm{T}}$-enrichment trend exhibited by all but one plagioclase-phyric sample (BCD1-12) in the current study. The fact that this plagioclase-phyric sample, together with the plagioclase-phyric sill (BCD5-55), lie to the "alkali" side of the trend, suggests that most of the deviations from this trend are caused by plagioclase accumulation. For the remaining aphyric samples, similar iron-enrichment trends across AFM-diagrams are typical for tholeiitic basalts derived from a common parental magma through fractional crystallisation. Even if the large age differences argue against all magmas being direct differentiates from each other, the well-defined major element trend on the AFM diagram indicates that several magmatic episodes could have generated roughly similar parental magmas, which subsequently evolved in more or less the same fashion.

\subsection{Variations due to fractional crystallisation}

In order to test the samples' apparent relationships further, a graphical method is applied to apparent linear trends within four variation diagrams displaying $\mathrm{MgO}, \mathrm{CaO}, \mathrm{Al}_{2} \mathrm{O}_{3}$ and $\mathrm{FeO}$ (Fig. 5(A-D)), in order to constrain fractionating assemblages with up to three different minerals (Ragland 1989). Realistic phase triangles are defined from plausible olivine, clinopyroxene and plagioclase compositions provided by GEOROC microprobe data from a number of Phanerozoic continental flood basalt 
provinces. Extrapolated manual best fit projections through these phase triangles result in four intercepts, which when re-plotted on the inserted ternary phase diagram in Fig. 5(D) can be made perfectly consistent with a fractionating assemblage of $57.5 \%$ plagioclase, $29.5 \%$ clinopyroxene and $13 \%$ olivine.

The average bulk fractionating assemblage derived above is used to forward model our "parental" BCD5-25/29 sample (with the lowest $\mathrm{MgO}$ ), assuming fractional crystallisation (FC) and applying generally accepted partition coefficients for these three phases in Ersoy and Helvaci's (2010) Excel spreadsheet. Such forward FC-models generally give reasonable fits with most incompatible trace element trends (not shown), and are consistent with up to $80 \%$ fractionation to produce the most "differentiated" BCD8-14 sample.

As illustrated by roughly sub-parallel patterns in the primitive mantle-normalised (Sun \& McDonough 1989) multi-element diagram (Fig. 6), a relationship based on fractional crystallisation is consistent with the older and more "primitive" samples (Fig. $6(\mathrm{~A}))$ having overall lower concentrations of incompatible elements compared to the younger and more "evolved" samples (Fig. 6(B)). Only Sr remains relatively constant in all samples, which is easily explained by the onset of plagioclase fractionation during differentiation from the more "primitive" to more "evolved" magmas. An apparent lack of any negative Ti-anomalies amongst all samples is consistent with insignificant ilmenite or titanomagnetite fractionation during differentiation, an observation supported by the tholeiitic trend in Figure 4(B), as well as systematic increases in $\mathrm{TiO}_{2}$ and $\mathrm{V}$ when plotted against decreasing magnesium number as a differentiation index (not shown).

\section{4. “Lithospheric” influences}

Despite obvious differentiation through crystal fractionation, a closer scrutiny of Fig. 6 also shows that older dykes have slightly more pronounced negative $\mathrm{Nb}$-anomalies and higher LILE/ HFSE ratios, consistent with a slightly greater "lithospheric" (subduction-zone related) component than observed amongst all but the plagioclase-phyric sample of the younger dykes. It is not easy to discriminate between whether this "lithospheric" component was inherited from (1) crustal assimilation of primary magmas derived from an asthenospheric mantle, or (2) more directly from the proto-Kalahari Craton's sub-continental lithospheric mantle (SCLM). The fact that this lithospheric component clearly affected earlier, less differentiated magmas more than subsequently more evolved magmas, is more consistent with either a greater involvement of SCLM during the formation of the older subgroup's primary magmas and/or earlier crustal assimilation of its parental magmas.

Counter-intuitive to a greater lithospheric component for the older sub-swarm, the more evolved younger subgroup, as a whole, tends to be slightly more LREE-enriched. This slight difference between the two age subgroups is consistent with each magmatic suite having been derived from two slightly different parental melts through the fractionation of a roughly similar gabbroic assemblage, as determined from consistent major element trends in Fig. 5. Thus, forward modelling of REEs confirms that the most elevated BCD8-14 pattern of the younger group cannot be derived from the least elevated BCD5-25/29 pattern from the older group purely through FC-modelling (see dashed thick line in Fig. 7(A)). Instead, the most evolved young dyke is better replicated through AFC-modelling of the most parental old dyke (see solid thick line in Fig. 7(A)), after $77 \%$ fractionation in addition to the assimilation of a bulk continental crust (Taylor $\&$ McLennan 1995) at an r-value of 0.2 (i.e., a relatively low ratio between the mass assimilation rate to the fractional crystallisation rate; Keskin 2013). The only problem with these two REE-models is that both generate patterns with distinctly more negative Eu-anomalies, where the uniquely steepest REE-pattern by the plagioclase-phyric dyke sample BCD1-12 also exhibits a slightly negative, rather than an expected positive Eu-anomaly.

As an alternative to the AFC-model in Fig. 7(A), the different REE-patterns for the two subgroups can also have been inherited from primary melts generated through different degrees of partial melting of the same mantle source, where more LREE-enriched (steeper) patterns for the younger subgroup resulted from lower degrees of partial melting. This cannot be the only explanation, however, since other incompatible elements behave oppositely (e.g., the LILE/HFSE-enriched older subgroup in Fig. 6 as opposed to the LREE-enriched younger subgroup in Fig. 7(A)) and therefore argue for different mantle type sources (e.g., variably depleted and/or metasomatically enriched SCLM, as well as different proportions of asthenospheric vs. lithospheric peridotite) and/or crustal assimilants. This could be investigated by a number of incompatible ratio diagrams, each of which highlight certain petrogenetic components but all of which cannot conclusively discriminate between these end-members.

As an example of a commonly used discrimination diagram by Pearce (2008), Fig. 8 shows how deviations above the Mantle Array may be caused by either (1) direct derivation from a mantle component that was metasomatised by typically LILE-enriched fluids from a subducting slab ("mantle wedge component" in Fig. 8(A)) or (2) through an asthenospheric melt's assimilation of a range of slightly different crustal components during fractional crystallisation (dashed arrow in Fig. 8(A)). In Fig. 8, the two age subgroups of the investigated BHDS plot as two slightly separate trends above the Mantle Array, with the older dykes distributed along the AFC-modelled trend between the Primordial Mantle and Bulk Crust and the younger dykes possibly trending away from a slightly more enriched part of the Mantle Array. Our old BCD5-25/29 parent sample is forward AFC-modelled in Ersoy and Helvaci's (2010) Excel spreadsheet, using the same parameters as for the modelled REEs in Fig. 7(A), and shown for reference by the solid arrow in Fig. 8(A). The modelling results' relatively poor fit in Fig. 8(A) (compared to the model's better fit for the REEs in Fig. 7(A)), illustrates how difficult it is to reach a petrogenetic conclusion based only on geochemical data.

Regardless of inconsistencies between some incompatible elements, it seems safe to conclude that the overall trend(s) expressed by our 11 data points range(s) between an ambient Primordial Mantle (PM) source and an Archaean Crust (AC) assimilant, as accentuated by associated sills and lavas in Fig. 8(B). Under closer scrutiny, it even appears that our two subgroups define two separate trends between AC and two slightly different asthenospheric mantle sources. Thus, the mantle source for our older subgroup appears to have been derived from a slightly more depleted, yet possibly also more metasomatically enriched (SCLM?) source, whereas our younger subgroup appears to have been derived from a slightly more enriched mantle source; both of which could also have been contaminated by Archaean Crust. 


\section{Discussion}

\subsection{Linking the 1879-1835 Ma BHDS to associated igneous rocks}

A compilation of high-precision U-Pb ages in Fig. 9(A) shows how our $c$. 1.875-1.835 Ga BHDS bridges a gap between the older $c$. 1.89-1.87 Ga ages of both Mashonaland (Söderlund et al. 2010; Hanson et al. 2011) and post-Waterberg (Hanson et al. 2004a) sills, and the youngest $c$. $1.83 \mathrm{Ga}$ zircon ages for pyroclastic rocks within the uppermost part of the Soutpansberg Group's Sibasa basalts (Geng et al. 2014). Thus the younger and geochemically matching BHDS (Fig. 7(B)) likely acted as feeders (indicated in red in Fig. 9(B)) to overlying nearby Sibasa basalts, and thereby collectively covered a $>10^{5} \mathrm{~km}^{2}$ area. Even if more ages and/or geochemical data are still needed to see how far back in time this particular flood basalt remnant erupted, it can be assumed that an even wider flood basalt cover was fed throughout the $>40 \mathrm{Myr}$ record of the BHDS. This is in accordance with speculations by Meinster (1977), Watkeys (1984), Cheney et al. (1990) and Barton and Pretorius (1997).

It is possible to consider the existence of an even more prolonged $>60$ Myr magmatic "Mashonaland-Soutpansberg" event, recorded by all ages in Figure 9(A), in which the earliest phase of magmatism was dominated by the emplacement of both Mashonaland and Waterberg sills. The Mashonaland sills have previously been geochemically matched to the BHDS (Klausen et al. 2010), but Fig. 7(D) shows that their REE-patterns bear closer resemblance to the younger Black Hills dykes than the older ones to which they are closer in age. Earlier correlations with Mazowe River dykes (MZ in Fig. 1(A)), dated by a poorly constrained $\mathrm{Rb}-\mathrm{Sr}$ age of $1900 \pm 600 \mathrm{Ma}$ and palaeomagnetic results (Wilson et al. 1987), are regarded with caution, because their depleted geochemical signatures do not match (Stubbs et al. 1999; Klausen et al. 2010). Söderlund et al. (2010) has shown how the Sebanga swarm, previously matched to Mashonaland sills on the basis of palaeomagnetic results (Bates \& Jones 1996; Hanson et al. 2004a), are c. 600-500 Ma older and also unrelated with the "Mashonaland-Soutpansberg" event. Nevertheless, the Mashonaland and post-Waterberg sills cover an even larger region, extending from the Waterberg Group on the Kaapvaal Craton to the northern part of the Zimbabwe Craton (indicated in green in Fig. 9(B)), north-west of and partly overlapping the BHDS-Sibasa area (outlined by dotted grey line in Fig. 9(B)). It is still uncertain (1) if/how this earlier emplacement of a sill complex was fed by a more extensive (longer and/or wider) NNE-NE-trending BHDS, (2) whether any other (eroded?) sills were fed by the younger BHDS, or (3) if Fig. 8(A) records a systematic temporal (and spatial) evolution from initial dyke-sill emplacement (in the west) to subsequent dyke-lava emplacement (in the east).

Only 20 Myr separate the $c .1 .89-1.83$ Ga magmatic "Mashonaland-Soutpansberg" event from an older c. 1.93-1.91 Ga "Hartley" event (Alebouyeh et al. this volume) consisting of volcanic rocks, sills and dykes covering a $\sim 10^{5} \mathrm{~km}^{2}$-large area across the south-western part of the Kalahari Craton (indicated by purple and outlined by another dotted line in Fig. 9(B)). It is tempting to view these igneous rocks as part of a coherent $c$. 100-Myr-long magmatic event. Even if the associated Tsineng dyke swarm extrapolates towards the outlined Soutpansberg "sub-province", its ENE-trend is slightly oblique to the more northerly trending BHDS. Cornell et al. (1998), furthermore, show that Hartley volcanic rocks are perhaps more "arc"-like (e.g., andesitic, LREE-enriched and pyroclastic) than the Sibasa basalts, so we still regard the two "sub-provinces" as separate entities (pulses?) within a more complex, long-lived but spatially very large igneous province. Although it is tempting to address the continuous $c .1 .89-1.83$ Ga magmatic activity across such a large area $\left(>5 \times 10^{5} \mathrm{~km}^{2}\right)$ as a voluminous LIP, with remnants of at least 3-km-thick flood basalt sequences, the available geochronology fails to show that a large proportion of the igneous rocks were produced within a sufficiently short time span (e.g., $<40$ Myrs as set by Bryan \& Ernst 2008), and that "time problem" becomes even greater if one merges the 60 Myr "Mashonaland-Soutpansberg" and $20 \mathrm{Myr}$ "Hartley" sub-provinces into a single protracted $\sim 100 \mathrm{Myr}-$ event.

\subsection{Tectono-magmatic setting and evolution}

Typical LIPs are often linked to mantle plumes (e.g. Ernst et al. 2005; Ernst 2014). Associated giant radiating or parallel swarms of doleritic dykes are hypothesised to be emplaced during crustal up-doming above a mantle plume head that impinges onto the base of a thick continental lithosphere (May 1971; Halls 1982; Ernst \& Buchan 1997). The excess heat from such plumes may melt the above lying more depleted SCLM over time if the SCLM has been sufficiently hydrated through past metasomatism. The plume itself may also decompressionally melt if the lithosphere thins sufficiently through extension. A mantle plume may thus, more or less directly, generate large volumes of basaltic magmas with a wide range of geochemical signatures.

Klausen et al.'s (2010) "mantle plume" model for the BHDS depends on an apparent radiating pattern that emerges from the extrapolated convergence of the BHDS and the presumed coeval Mazowe River dyke swarm in northern Zimbabwe (Fig. 1(B)). These swarms share a common locus to the north-east of the Zimbabwe Craton, where also the greatest preserved concentration of Mashonaland sills occurs (Fig. 10(C) in Klausen et al. 2010). We emphasise the uncertainties, however, concerning the age of the Mazowe River dyke swarm and also question whether such depleted magmas can in any way be reconciled with a mantle plume or even just the Primordial Mantle signatures expressed by all of the precisely dated rocks in this study. Thus, until reliable age constraints are presented on the Mazowe River dyke swarm (or any other coeval dyke swarm in the Zimbabwe Craton), this convergence towards a possible mantle plume centre remains speculative.

A more southerly located locus for a triple rift system is suggested by Jansen's (1975) idea of the Soutpansberg Basin representing a failed-rift arm (an aulacogen). In this case, coeval strata along an eastern passive plate-margin side of the proto-Kalahari Craton (Fig. 9(B)) could have been obliterated by the Mozambique Belt that formed during a c. 550 Ma Pan-African orogeny.

Potential candidates for a conjugate passive margin along another continental fragment may be found amongst a myriad of coeval c. $1.88 \mathrm{Ga}$ magmatic events recorded across the globe (reviewed by Minifie et al. 2011); many of which fringe the Superior Craton (Minifie et al. 2013), whereas others outcrop more sporadically on the Slave, Wyoming, Baltic, Indian and Australian cratons. Since many Columbia palaeo-supercontinental reconstructions join the proto-Kalahari craton with Australia, the studied proto-Kalahari Craton "LIP" fragment may most likely be linked to the Yilgarn's volcano-sedimentary Yerrida basin. The Yerrida 

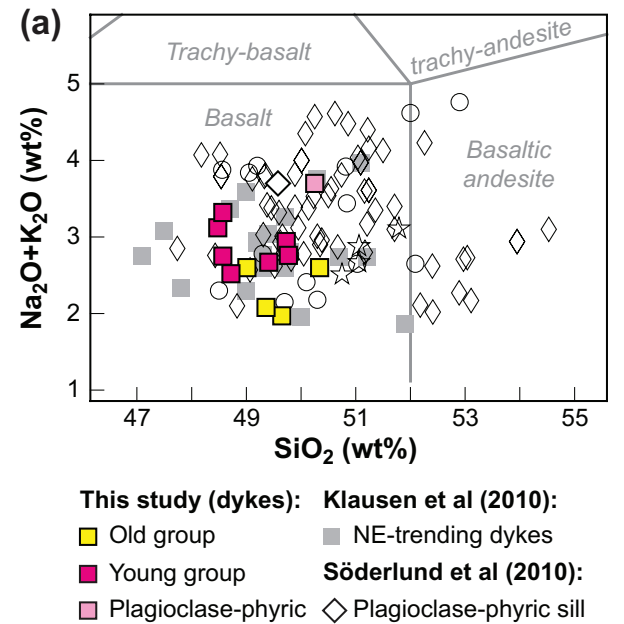

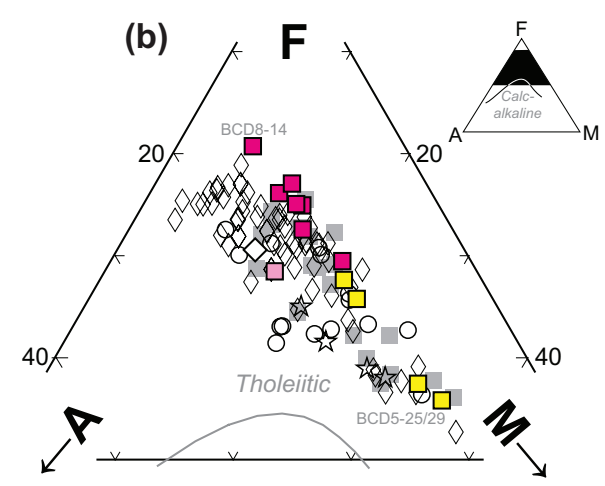

Bumby et al (2001), Crow \& Condie (1990):

O Basaltic lavas from the Sibasa Formation

Stubbs (2000): $\quad$ Hanson et al (2004):

$\diamond$ Mashonaland sills is Waterberg-hosted sills

Fig. 4. Major element classification diagrams: A. Total Alkali versus Silica (TAS; Le Maitre 2002) and B. total Alkalies (A) versus total FeO (F) versus MgO (M) (AFM; Irvine \& Baragar 1971).

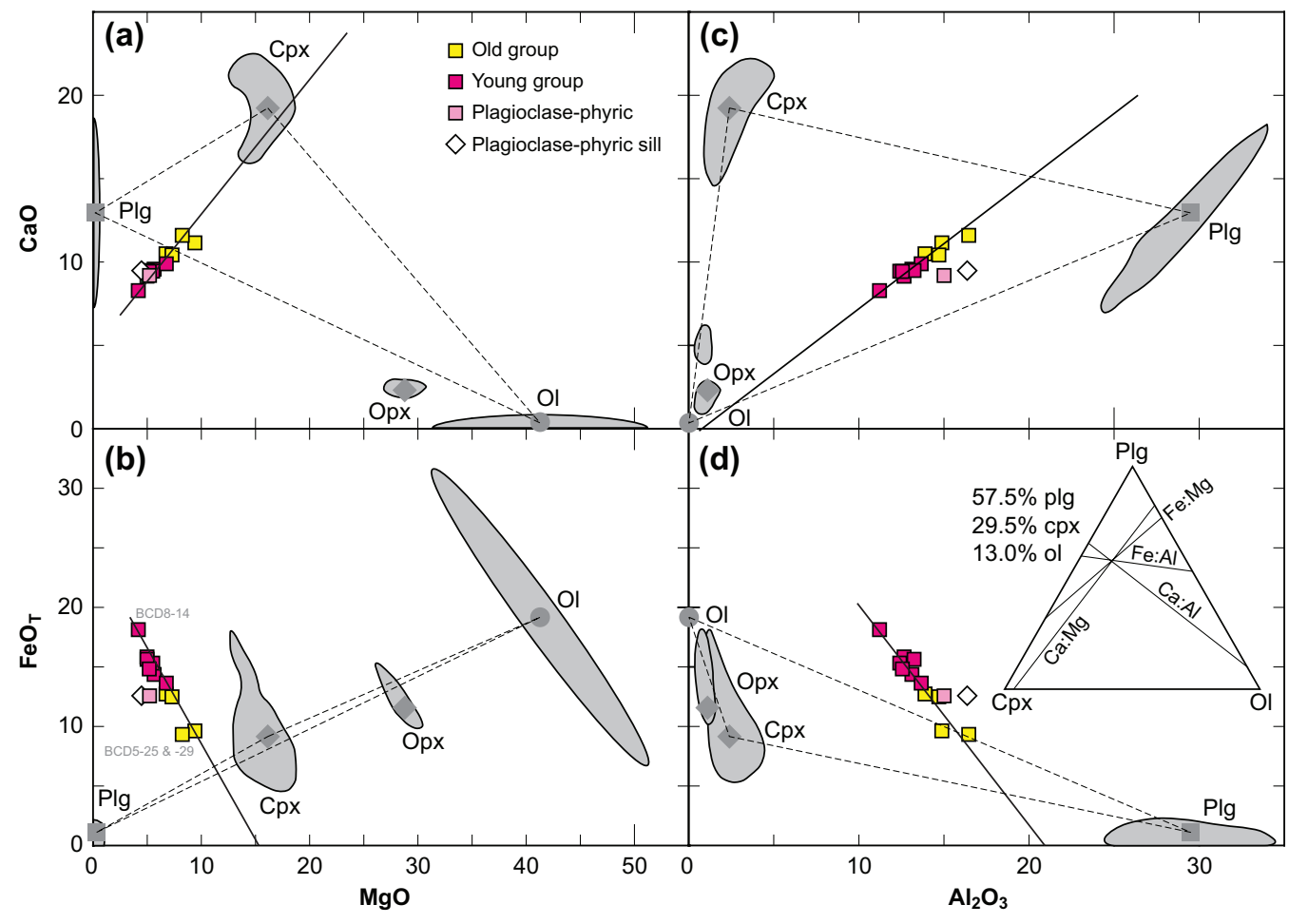

Fig. 5. Four major element variation diagrams selected to graphically constrain fractionating mineral assemblages, following Ragland (1989). Solid black lines are manually fitted to trends and extrapolated across dashed triangles that link likely average compositions of olivine (ol), clinopyroxene (cpx) and plagioclase (plg), all of which lie inside compositional (grey) fields derived from GEOROC's (2012) data base of microprobe analyses on Phanerozoic continental flood basalts. Inserted ternary diagram shows how well the extrapolated trends intersect these phase triangles in each of the four variation diagrams, and thereby determining a possible fractionating assemblage consisting of 57.5\% plg, $29.5 \% \mathrm{cpx}$ and $13.0 \% \mathrm{ol}$.

basin hosts 50-m-thick mafic sills that have been indirectly dated by $\mathrm{U}-\mathrm{Pb}$ SHRIMP on hydrothermal monazite in its host shale to $1843 \pm 10 \mathrm{Ma}$ (Rasmussen \& Fletcher 2002). Together with the $c$. $1.87 \mathrm{Ga}$ Bow River, $c .1 .85 \mathrm{Ga}$ Sally Maly and $c .1 .83 \mathrm{Ga}$ Edmirringee "sub-provinces" (Claoué-Long \& Hoatson 2010), this potential "Australian" counterpart records a conspicuously similar protracted c. 40 Myr-period of mafic magmatism. Future testing of such correlations and reconstructions would require more data on mafic rocks of appropriate age on the Australian continent; e.g., in order to determine whether Pilbara resided along Kaapvaal's eastern "passive" margin (Zegers et al. 1998) or its western margin, as suggested by de Kock et al.'s (2009) "Vaalbara" concept.

As opposed to a break-up-related LIP setting, the Soutpansberg Basin has also been correlated with east-vergent compressional tectonics along the Kheis Belt on the western margin of the Kaapvaal Craton (e.g. Silver et al. 2004). These authors 


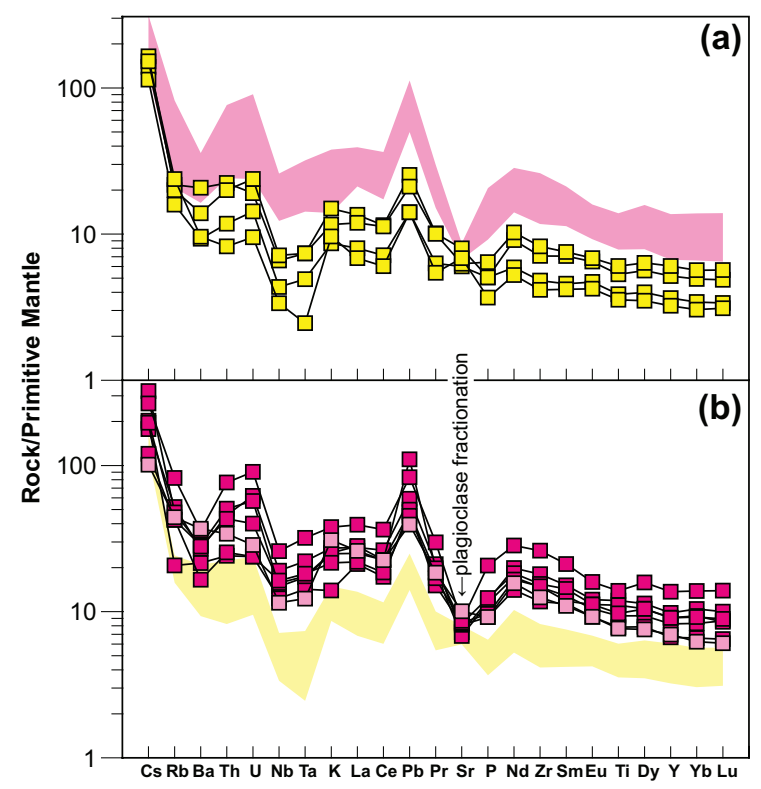

Fig. 6. Primitive mantle-normalised multi-element diagram (Sun \& McDonough 1989) displaying A. the older (yellow) and B. the younger (magenta) dyke subsets of the Black Hills swarm. Symbols as in Fig. 4 and shaded outlines as in Fig. 7.

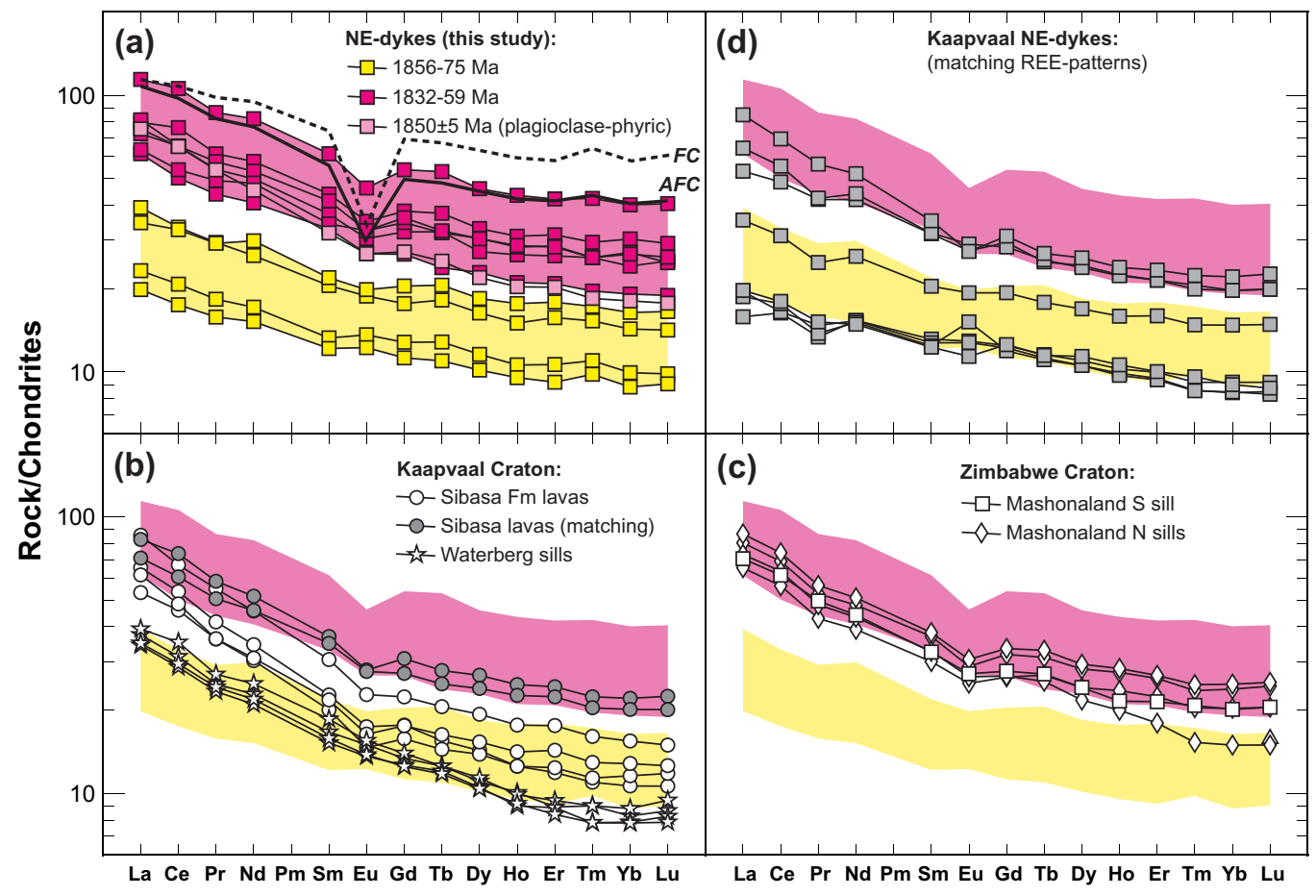

Fig. 7. Four chondrite-normalised REE-diagrams according to Sun and McDonough (1989) depicting patterns for A. both older and younger NE-trending dykes from this study, whose shaded outlines are compared to published data on B. broadly coeval lavas (Bumby et al. 2001, Crow \& Condie 1990) and sills (Hanson et al. 2004a) from within the Kaapvaal Craton, C. other non-dated NE-trending dykes across the Kaapvaal Craton (Klausen et al. 2010) with similar REE-patterns as the dated BHDS, and D. broadly coeval sills and dykes from within the Zimbabwe Craton matching Stubbs et al. (1999) and Stubbs (2000). Using the lowermost curve (BCD5-25/29 as a parental melt), the dashed thick curve labelled $\boldsymbol{F C}$ in (A) follows $88 \%$ fractionation of a gabbroic mineral assemblage, as constrained in Fig. 5, whereas a better fit by the solid thick curve labelled AFC in (A) with the most evolved REE-pattern is achieved by $77 \%$ fractionation and assimilation of a bulk continental crust (Taylor \& McLennan 1995), at an r-value of 0.2. Symbols as in Fig. 4.

further elaborate on the possibility that Archaean-Proterozoic rift basins and major flood basalt provinces in southern Africa followed pre-existing lithospheric structures produced dur- ing earlier collision phases. Thus, Bumby et al. (2002) viewed the Soutpansberg Basin as a half-graben produced during the collapse of the Limpopo Mountains. However, we consider such 


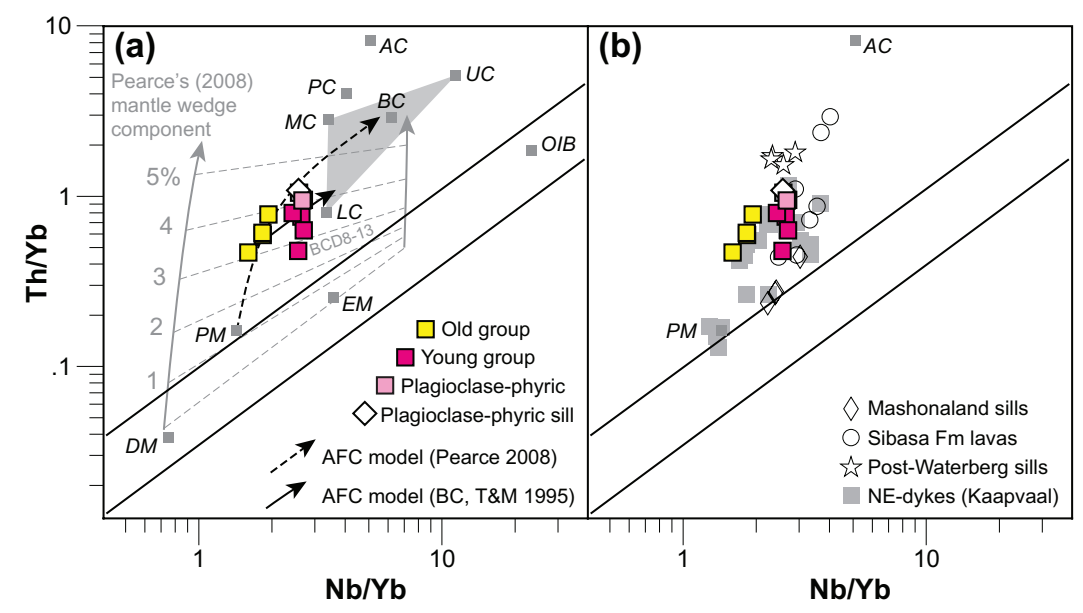

Fig. 8. In these $\mathrm{Th} / \mathrm{Yb}$ versus $\mathrm{Nb} / \mathrm{Yb}$ diagrams, more residual garnet in a deeper and more enriched mantle source lowers the common denominator $\mathrm{Yb}$, shifting compositions toward higher ratios along the mantle array. Subduction zones generally have lower $\mathrm{Nb}$, whereas Archaean crustal sources tend to be more enriched in Th. Any of these components tend to shift compositions away from the mantle array, as indicated by the grey "subduction component grid" and dashed AFC arrow taken from Pearce (2008). The AFC model in Fig. 7(A) is indicated by the solid black arrow (T\&M = Taylor \& McLennan 1995). DM = Depleted Mantle, PM = Primordial Mantle, EM = Enriched mantle, OIB = Oceanic Island Basalt source, $\mathrm{LC}=$ Lower Crust, $\mathrm{MC}=$ Middle Crust, $\mathrm{UC}=$ Upper Crust, $\mathrm{BC}=$ Bulk Crust, $\mathrm{PC}=$ Phanerozoic Crust, AC = Archaean Crust. Symbols as in Fig. 4.

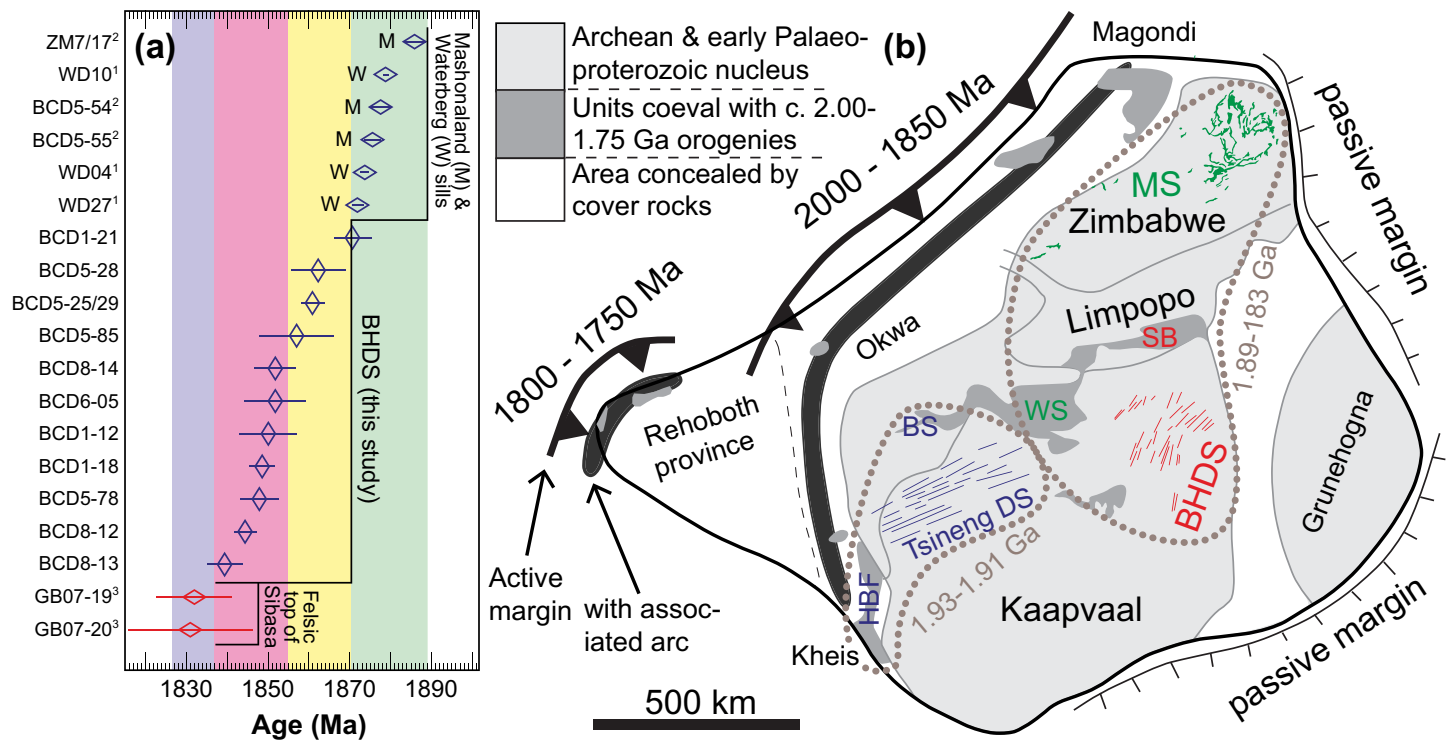

Fig. 9. A. Compilation of precise ages (with $2 \sigma$ error-bars) for all 11 dykes that are dated in this paper, as well as associated post-Waterberg sills $(1=$ Hanson et al. 2004a), Mashonaland sills (2 = Söderlund et al. 2010) and the top of the Sibasa lava formation ( $3=$ Geng et al. 2014). Background colours emphasise periods of earliest sill emplacement (green), followed by early (yellow) and late (magenta) dyke emplacement, which probably fed Sibasa lavas up to its more evolved pyroclastic cap (purple). B. Schematic tectonic map of the proto-Kalahari Craton, (introduced in Fig. 1(A)), modified from Jacobs et al. (2008) and showing relative positions of the Zimbabwe, Kaapvaal and Grunehogna cratons as well as the Limpopo Mobile Belt at $\boldsymbol{c}$. $1750 \mathrm{Ma}$. Here, the Magondi, Okwa and Kheis tectonic elements are arguably connected through a $\boldsymbol{c}$. 2.00-1.85 Ga subduction zone and associated back-arc extension. and the subduction associated with the Rehoboth province is set at $\boldsymbol{c}$. 1.80-1.75 Ga. Added onto the map, in red, are the coeval BHDS at least 3-km-thick Soutpansberg-hosted Basalts (SB; Bumby et al. 2001), in green are Waterberg-hosted sills (WS; Hanson et al. 2004a) and Mashonaland sills (MS; Stubbs et al. 1999; Söderlund et al. 2010), which are believed to constitute the eroded known remains of a temporally continuous $\boldsymbol{c} .1 .89-1.83 \mathrm{Ga}$ "Mashonaland-Soutpansberg" igneous province across the proto-Kalahari Craton. Also added are, in dark blue, slightly older (c. 1.93-1.91 Ga) Hartley basalt formation (HBF), Botswana sill complex (BS; Hanson et al. 2004a) and the Tsineng dyke swarm (Alebouyeh et al. this volume).

a post-orogenic setting highly unlikely to produce the recorded vast emplacement of basaltic dykes, extensive sill complexes and associated flood basalts during a c. 60 Myr period.

Klausen et al. (2010) also speculated upon a continental back-arc rift origin for the BHDS, during a complex tectonic setting with SE-directed subduction along the Magondi Belt. The timing and nature of compression along the western margin of the proto-Kalahari Craton is not sufficiently well established, however, especially with regard to determining whether the Magondi and Okwa-Kheis tectonic elements (and even 
the Reheboth Province) formed a continuous belt or not. Even though Moen and Armstrong (2008) argue that the Kheis Belt was deformed during a much younger Namaqua Orogeny, a coeval (Palaeoproterozoic) active margin along the north-western margin of the proto-Kalahari Craton is supported by $\mathrm{U}-\mathrm{Pb}$ dating on detrital zircons found in sedimentary units, yielding ages of (1) c. $1.85 \mathrm{Ga}$ in the upper Soutpansberg basin (Dorland 2004), (2) $1887 \pm 14 \mathrm{Ma}$ in the Okwa Group in Botswana (Ramokate et al. 2000), (3) $1858 \pm 14 \mathrm{Ma}$ in the Palapye Group in northern Kaapvaal Craton (Mapeo et al. 2004) and (4) c. $1.87 \mathrm{Ga}$ in the Billstein Quartzite of the Rehoboth Province (Van Schijndel et al. 2011). We prefer to view these results as indicative of Palaeoproterozoic silicic rocks having formed along the western and northern Kaapvaal Craton margin, contemporaneous with the emplacement of a more inland proto-Kalahari Craton "Mashonaland-Soutpansberg" ( \pm "Hartley") igneous province.

According to Van Niekerk (2009), the high Th/U ratios of c. $1.85 \mathrm{Ga}$ detrital zircons in the Kheis province might reflect a source rock of granitic composition rather than metamorphic sources. If the detrital zircons originated from magmatic silicic rocks produced during a complex subduction zone setting, the BHDS could have been emplaced in a corresponding continental back-arc basin, as tentatively shown in Fig. 9(B). Such a tectono-magmatic setting is consistent with large volumes of mantle-derived magma emplaced over a prolonged period of $\sim 60$ (-100) Myrs, a sub-parallel orientation of the BHDS, and possibly even some of the geochemical "subduction-zone" signatures that were tentatively attributed to a continental lithospheric component above.

If the BHDS and associated igneous rocks formed within such a trans-Kalahari Craton tectono-magmatic setting, this event could still have been part of a more global distribution of roughly coeval LIPs (e.g., Minifie et al. 2011), discussed above. Thus, some or all of these coeval - and often presumed breakup-related LIPs - could also have formed during an amalgamation - rather than a break up - of the Columbia (Nuna) palaeo-supercontinent, with or without the influences from plumes, or even a superplume. Further research into these LIPs is required, however, before the underlying petrotectonic causes for this global magmatic event are better understood.

\section{Summary and conclusions}

$\mathrm{U}-\mathrm{Pb}$ Isotope Dilution Thermal Ionisation Mass Spectrometry (ID-TIMS) baddeleyite dating of eleven tholeiitic dolerites from the NNE-NE-trending BHDS, covering $~ 35000 \mathrm{~km}^{2}$ of the north-eastern Kaapvaal Craton, suggests an emplacement age span of 1875-1835 Ma. There is no systematic correlation between ages and either location or dyke trends, but older dykes tend to be less differentiated than younger ones. Reversed modelling of some very linear major element trends explains this differentiation by nearly $80 \%$ fractionation of $57.5 \%$ plagioclase, $29.5 \%$ clinopyroxene and $13 \%$ olivine, where forward modelling of REEs requires additional assimilation by our parental sample of a bulk continental crust at an r-value of only 0.2 .

We first link the BHDS to nearby and compositionally similar c. 1879-1872 Ma post-Waterberg sills (Hanson et al. 2004a) and $\geq 1830$ Ma Sibasa basalt flows in the Soutpansberg Basin (Geng et al. 2014), covering $\sim 10^{5} \mathrm{~km}^{2}$ of the Kaapvaal Craton. These post-Waterberg sills are coeval and compositionally similar to Mashonaland sills (Stubbs et al. 1999; Söderlund et al. 2010), on the Zimbabwe Craton, indicating that they form a large (trans-Kalahari Craton) igneous province. This province may even be larger and of a longer (c. $100 \mathrm{Myr}$ ) duration if combined with 1.93-1.91 Ga Tsineng dyke swarm, Botswana sills and Hartley lavas (Fig. 9(B); Alebouyeh et al. this volume).

Overall, incompatible element ratio trends for all of Soutpanberg's trans-Kalahari Craton magmas are consistent with being derived from an ambient asthenospheric Primordial Mantle, all of which underwent a similar AFC-process of assimilating Archaean crust, in proportions quantified above. This is remarkable for magmas that over a $\sim 60 \mathrm{Myr}$ period were successively generated, differentiated and emplaced across a $>5 \times 10^{5} \mathrm{~km}^{2}$-large region. The long duration of this continuous magmatism argues against these magma volumes to have been produced during typical plume-induced break-up of a supercontinent. Instead, there is an abundance of more or less convincing field, structural and geochronological evidence for a continental back-arc setting, behind an active Magondi and Okwa-Kheis arc along the north-western margin of the proto-Kalahari Craton, which may link to a global distribution of coeval tectono-magmatic settings (Minifie et al. 2011) that arguably formed during the amalgamation of the Columbia (Nuna) supercontinent, and where the proto-Kalahari Craton most likely neighboured Australia.

Acknowledgements---This research was supported by the Swedish Research Council through a grant to US and the Crafoord Foundation through a grant to JRO. MBK acknowledges South Africa's National Research Foundation for their support. JRO thanks Hennie Coetzee and Marius Porteus at Foskor INC and Tawanda Manyeruke at NKWE Platinum for kindly providing core samples and maps. The staff at LIG (Stockholm) and JSGL (Toronto) are thanked for their generous help during U-Pb analytical sessions. Richard Hanson, an anonymous reviewer and Lithos editor Andrew Kerr provided helpful comments on an early version of the manuscript. Two additional anonymous reviewers and volume editor Wouter Bleeker especially improved our final presentation of the paper.

Funding---This work was supported by National Research Foundation [grant number 65785]

\section{References}

Alebouyeh, F.A., Söderlund, U., de Kock, M. \& Gumsley, A., this volume: U-Pb geochronology and paleomagnetic constraints of the large-scale late Paleoproterozoic Hartley magmatic event from the Kaapvaal Craton, South Africa. GFF.

Barker, O.B., 1976: Discussion of paper by H. Jansen. The Soutpansberg trough (northern Transvaal) - an aulacogen. Transactions of Geological Society of South Africa 79, 146-148.

Barker, O.B., Brandl, G., Callaghan, C.C., Eriksson, P.G. \& van der Neut, M., 2006: The Soutpansberg and Waterberg Groups and the Blouberg Formation. In M.R. Johnson, C.R. Anhaeusser \& Thomas, R.J. (eds.): The geology of South Africa, 301-318. Geological Society of South Africa, Johannesburg/ Council for Geoscience, Pretoria.

Barton, J.M., Jr., 1979: The chemical compositions, Rb-Sr isotopic systematics and tectonic setting of certain post-kinematic mafic igneous rocks, Limpopo Mobile Belt, Southern Africa. Precambrian Research 9, 57-80.

Barton, J.M. \& Pretorius, W., 1997: The lower unconformity-bounded sequence of the Soutpansberg Group and its correlatives; remnants of a Proterozoic large igneous province. South African Journal of Geology 100, 335-339.

Bates, M.P. \& Jones, D.L., 1996: A palaeomagnetic investigation of the Mashonaland dolerites, north-east Zimbabwe. Geophysical Journal International 126, 513-524.

Bleeker, W., 2003: The late Archean record: a puzzle in ca. 35 pieces. Lithos 71, 99-134.

Bleeker, W., 2004: Taking the pulse of planet Earth: a proposal for a new multi-disciplinary flagship project in Canadian solid Earth sciences. Geoscience Canada 31, 179-190.

Brandl, G., Cloete, M. \& Anhaeusser, C.R., 2006: Archaean greenstone belts. In M.R. Johnson, C.R. Anhaeusser \& R.J. Thomas (eds.): The geology of South 
Africa, 9-56. Geological Society of South Africa, Johannesburg/Council for Geoscience, Pretoria.

Bryan, S.E. \& Ernst, R.E., 2008: Revised definition of Large Igneous Provinces (LIPs). Earth-Science Reviews 86, 175-202.

Bumby, A.J., Eriksson, P.G., van der Merwe, R. \& Maier, W.D., 2001: The stratigraphic relationship between the Waterberg and Soutpansberg Groups in Northern Province, South Africa: Evidence from the Blouberg area. South African Journal of Geology 104, 205-216.

Bumby, A.J., Eriksson, P.G. \& van der Merwe R. \& Steyn, G.L., 2002: A half-graben setting for the Proterozoic Soutpansberg Group (South Africa): evidence from the Blouberg area. Sedimentary Geology 147, 37-56.

Cahen, L., Snelling, N.J., Delhal, J. \& Vail, J.R., 1984: The Geochronology and Evolution of Africa. Oxford University Press, New York

Cheney, E.S., Barton, J.M. \& Brandl, G., 1990: Extent and age of the Soutpansberg sequences of southern Africa. South African Journal of Geology 93, 664-675.

Claoué-Long, J.C. \& Hoatson, D., 2010: Australian LIPs and the Australian Precambrian 'barcode'. October 2010 LIP of the Month. www.largeigneousprovinces.org.

Coffin, M.F. \& Eldholm, O. 1994: Large igneous provinces: crustal structure, dimensions, and external consequences. Reviews of Geophysics 32, 1-36.

Compston, W. \& McElhinny, M.W., 1975: The Rb-Sr age of the Mashonaland dolerites of Rhodesia and its significance for paleomagnetic correlation in southern Africa. Precambrian Research 2, 305-315.

Cornell, D.H., Armstrong, R.A. \& Walraven, F., 1998: Geochronology of the Proterozoic Hartley Basalt formation, South Africa: constraints on the Kheis tectogenesis and the Kaapvaal Craton's earliest Wilson Cycle. Journal of African Earth Sciences 26, 5-27.

Cox, K.G., 1988: The Karoo Province. In J.D. MacDougall (ed.): Continental flood basalts, 239-271. Kluwer Academic, Dordrecht.

Crow, C. \& Condie, K.C., 1990: Geochemistry and origin of early Proterozoic volcanic rocks from the Transvaal and Soutpansberg successions, South Africa. Precambrian Research 47, 17-26.

Davidson, A. \& van Breemen, O., 1988: Baddeleyite-zircon relationships in coronitic metagabbro, Grenville Province, Ontario: implications for geochronology. Contributions to Mineralogy and Petrology 100, 291-299.

de Kock, M.O., Evans, D.A.D. \& Beukes, N.J., 2009: Validating the existence of Vaalbara in the Neoarchean. Precambrian Research 174, 145-154.

de Kock, M.O., Ernst, R., Söderlund, U., Jourdan, F., Hofmann, A., Le Gall, B., Bertrand, H., Chisonga, B.C., Beukes, N., Rajesh, H.M., Moseki, L.M. \& Fuchs, R., 2014: Dykes of the 1.11 Ga Umkondo LIP, Southern Africa: clues to acomplex plumbing system. Precambrian Research 249, 129-143.

Dorland, H.C., 2004: Provenance ages and timing of sedimentation of selected Neoarchean and Paleoproterozoic successions on the Kaapvaal craton. Unpublished Ph. D. thesis, Rand Afrikaans University, Johannesburg, 326 pp.

Dorland, H.C., Beukes, N.J., Gutzmer, J., Evans, D.A.D. \& Armstrong, R.A., 2006: Precise SHRIMP U-Pb zircon age constraints on the lower Waterberg and Soutpansberg Groups, South Africa. South African Journal of Geology 109, 139-156.

Eriksson, P.G., Altermann, W., Catuneanu, O., van der Merwe, R. \& Bumby, A.J., 2001: Major influences on the evolution of the 2.67-2.1 Ga Transvaal basin, Kaapvaal craton. Sedimentary Geology 141-142, 205-231.

Ernst, R.E., 2014: Large igneous provinces. Cambridge University Press, Cambridge. 653 pp.

Ernst, R.E. \& Buchan, K.L., 1997: Giant radiating dyke swarms: their use in identifying pre-Mesozoic large igneous provinces and mantle plumes. American Geophysical Union Monograph 100, 297-333.

Ernst, R.E., Buchan, K.L. \& Campbell, I.H., 2005: Frontiers in large igneous province research. Lithos 79, 271-297.

Ersoy, Y. \& Helvaci, C., 2010: FC-AFC-FCA and mixing modeler: a Microsoft ${ }^{\circledR}$ Excel(C) spreadsheet program for modelling geochemical differentiation of magma by crustal fractionation, crustal assimilation and mixing. Computers \& Geosciences 36, 383-390.

Geng, H., Brandl, G., Sun, M., Wonga, J. \& Kröner, A., 2014: Zircon ages defining deposition of the Palaeoproterozoic Soutpansberg Group and further evidence for Eoarchaean crust in South Africa. Precambrian Research 249 247-262.

Gerstenberger, H. \& Haase, G., 1997: A highly effective emitter substance for mass spectrometric $\mathrm{Pb}$ isotope ratio determinations. Chemical Geology 136 , 309-312.

Gumsley, A.P., de Kock, M.O., Rajesh, H.M., Knoper, M.W., Söderlund, U. \& Ernst, R.E., 2013: The Hlagothi Complex: the identification of fragments from a Mesoarchaean large igneous province on the Kaapvaal Craton. Lithos 174 $333-348$.

Gumsley, A., Olsson, J.R., Söderlund, U., de Kock, M., Hofmann, A. \& Klausen, M.B., 2015: Precise U-Pb baddeleyite age dating of the Usushwana Complex, southern Africa - implications for the Mesoarchaean magmatic and sedimentological evolution of the Pongola Supergroup, Kaapvaal Craton. Precambrian Research. 267, 174-185

Gumsley, A., Rådman, J., Söderlund, U. \& Klausen, M.B. this volume. U-Pb baddeleyite geochronology and geochemistry of the White Mfolozi Dyke Swarm: unravelling the complexities of 2.70-2.66 Ga dyke swarms on across the eastern Kaapvaal Craton, South Africa. GFF.
Halls, H.C., 1982: The importance and potential of mafic dyke swarms in studies of geodynamic processes. Geoscience Canada 9, 145-154.

Hanson, R.E., Gose, W.A., Crowley, J.J., Ramezani, J., Bowring, S.A., Bullen, D.S., Hall, R.P., Pancake, J.A. \& Mukwakwami, J., 2004a: Paleoproterozoic intraplate magmatism and basin development of the Kaapvaal Craton: age, paleomagnetism and geochemistry of $\sim 1.93$ to $\sim 1.87$ Ga post-Waterberg dolerites. South African Journal of Geology 107, 233-254.

Hanson, R.E., Crowley, J.L., Bowring, S.A., Ramezani, J., Gose, W.A., Dalziel, I.W.D., Pancake, J.A., Seidel, E.K., Blenkinsop, T.G. \& Mukwakwami, J., 2004b: Coeval large-scale magmatism in the Kalahari and Laurentian cratons during Rodinia assembly. Science 304, 1126-1129.

Hanson, R.E., Riox, M., Gose, W.A., Blackburn, T.J., Bowring, S.A., Mukwakwami, J. \& Jones, D.L., 2011: Paleomagnetic and geochronological evidence for large-scale post-1.88 Ga displacement between the Zimbabwe and Kaapvaal cratons along the Limpopo belt. Geology 39, 487-490.

Hartnady, C.J., Joubert, P. \& Stowe, C., 1985: Proterozoic crustal evolution in southwestern Africa. Episodes 8, 236-244.

Heaman, L.M. \& LeCheminant, A.N., 1993: Paragenesis and U-Pb systematics of baddeleyite $\left(\mathrm{ZrO}_{2}\right)$. Chemical Geology 110, 95-126.

Holzer, L., Frei, R., Barton, J.M. \& Kramers, J.D., 1998: Unraveling the record of successive high grade events in the Central Zone of the Limpopo Belt using $\mathrm{Pb}$ single phase dating of metamorphic minerals. Precambrian Research 87 , $87-115$.

Irvine, T.N. \& Baragar, W.R.A., 1971: A guide to the chemical classification of the common volcanic rocks. Canadian Journal of Earth Sciences 8, 523-548.

Jacobs, J., Pisarevsky, S., Thomas, R.J. \& Becker, T., 2008: The Kalahari Craton during the assembly and dispersal of Rodinia. Precambrian Research 160, $142-158$.

Jansen, H., 1975: The Soutpansberg trough (northern Transvaal) - an aulacogen. Transactions of Geological Society of South Africa 78, 129-136.

Jaffey, A.H., Flynn, K.F., Glendenin, L.E., Bentley, W.C. \& Essling, A.M., 1971: Precision measurements of half-lives and specific activities of ${ }^{235} \mathrm{U}$ and ${ }^{238} \mathrm{U}$. Physical Review 4, 1889-1906.

Johnson, M.R., Anhaeusser, C.R. \& Thomas, R.J.,2006: The Geology of South Africa. Geological Society of South Africa, Johannesburg/Council of Geoscience, Pretoria. $691 \mathrm{pp}$

Jourdan, F., Féraud, G., Bertrand, H., Kampunzu, A.B., Tshoso, G., Watkeys, M.K. \& Le Gal, B., 2005: Karoo large igneous province: brevity, origin and relation to mass extinction questioned by new ${ }^{40} \mathrm{Ar} /{ }^{39} \mathrm{Ar}$ age data. Geology 33 , $745-748$.

Jourdan, F., Féraud, G., Bertrand, H., Watkeys, M.K., Kampunzu, A.B. \& Le Gall, B., 2006: Basement control on dyke distribution in Large Igneous Provinces: Case study of the Karoo triple junction. Earth and Planetary Science Letters 241,307-322.

Keskin, M., 2013: AFC-Modeler: a Microsoft $₫$ Excel@ workbook program for modelling assimilation combined with fractional crystallization (AFC) process in magmatic systems by using equations of DePaolo (1981). Turkish Journal of Earth Sciences 22, 304-319.

Klausen, M.B., Söderlund, U., Olsson, J.R., Ernst, R.E., Armoogam, M., Mkhize, S.W. \& Petzer, G., 2010: Petrological discrimination among Precambrian dyke swarms: Eastern Kaapvaal craton (South Africa). Precambrian Research $183,501-522$

Kramers, J.D., McCourt, S. \& van Reenen, D.D., 2006: The Limpopo Belt. In M.R. Johnson, C.R. Anhaeusser \& R.J. Thomas (eds.): The geology of South Africa, 209-236. Geological Society of South Africa Johannesburg/Council for Geoscience Pretoria.

Le Maitre, R.W., 2002: A classification of igneous rocks and glossary of terms, 2nd ed. Blackwell Scientific, Oxford, $236 \mathrm{pp}$.

Lubnina, L., Ernst, R.E., Klausen, M.B. \& Söderlund, U., 2010: Paleomagnetic study of NeoArchean - Paleoproterozoic dykes in the Kaapvaal Craton. Precambrian Research 183, 523-552.

Ludwig, K.R., 1991: Isoplot - a plotting and regression program for radiogenic isotopic data. USGS Open-File report 91-445.

Ludwig, K.R., 2003: Isoplot 3.00; A geochronological toolkit for Microsoft Excel. Berkely Geochronological Center Publication 4.

Mapeo, R.B.M., Kampuznu, A.B., Ramokate, L.V., Corfu, F. \& Key, R.M. 2004: Bushveld-age magmatism in southeastern Botswana: evidence from U-Pb zircon and titanite geochronology of the Moshaneng Complex. South African Journal of Geology 107, 219-232

Mapeo, R.B.M., Ramokate, L.V., Corfu, F., Davis, D.W. \& Kampunzu, A.B., 2006: The Okwa basement complex, western Botswana: U-Pb zircon geochronology and implications for Eburnean processes in southern Africa. Journal of African Earth Sciences 46, 253-262.

März, N., 2011: When did the Kalahari craton form? Constraints from baddeleyite U-Pb geochronology and geochemistry of mafic intrusions in the Kaapvaal and Zimbabwe cratons. Unpublished M. Sc. thesis, Lunds Universitet. $35 \mathrm{pp}$.

Master, S., 1994: Geodynamic evolution and correlation of the Magondi Belt (Zimbabwe): implications for the Palaeoproterozoic history of Botswana. Botswana Journal of Earth Sciences 2, 25-32.

Master, S., Bekker, A. \& Hofmann, A., 2010: A review of the stratigraphy and geological setting of the Palaeoproterozoic Magondi Supergroup, Zimbabwe - Type locality for the Lomagundi carbon isotope excursion. Precambrian Research 182, 254-273. 
May, P.R., 1971: Pattern of Triassic-Jurassic diabase dikes around the North Atlantic in the context of the predrift position of the continents. Geological Society of America Bulletin 82, 1285-1292.

Meinster, B., 1977: Discussion of paper by H. Jansen, The Soutpansberg trough (northern Transvaal) - an aulacogen. Transactions of Geological Society of South Africa 80, 289-298

Minifie M.J., Ernst, R.E. \& Kerr, A.C., 2011: Geochemistry of global ca. 1880 Ma LIP magmatism: is there evidence for a comagmatic origin and connections in supercontinent reconstructions? April 2011 LIP of the Month. www.largeigneousprovinces.org.

Minifie, M.J., Kerr, A.C., Ernst, R.E., Hastie, A.R., Ciborowski, T.J.R., Desharnais, G. \& Millar, I.L., 2013: The northern and southern sections of the western ca. 1880 Ma circum-superior large igneous province, North America: the Pickle Crow dyke connection? Lithos 174, 217-235. doi: http://dx.doi.org/10.1016/j.lithos.2012.03.017.

Mkhize, S.W., 2008: Geochemical and petrographical characterization of mafic dyke swarms across the north-eastern Kaapvaal craton. Unpublished honours thesis. University of KwaZulu-Natal, Durban, 87 pp.

Moen, H.F.G., 1999: The Kheis Tectonic Subprovince, southern Africa: a lithostratigraphic perspective. South African Journal of Geology 102, 27-42.

Moen, H.F.G., 2006: The Olifantshoek Supergroup. In M.R. Johnson, C.R. Anhaeusser \& R.J. Thomas (eds.): The geology of South Africa, 319-324. Geological Society of South Africa Johannesburg/Council for Geoscience Pretoria.

Moen, H.F.G. \& Armstrong, R.A., 2008: New age constraints on the tectogenesis of the Kheis Subprovince and the evolution of the eastern Namaqua Province. South African Journal of Geology 111, 79-88.

Ohta, T. \& Arai, H., 2007: Statistical empirical index of chemical weathering in igneous rocks: a new tool for evaluating the degree of weathering. Chemical Geology 240, 280-297.

Olsson, J.R., 2012: U-Pb baddeleyite geochronology of Precambrian mafic dyke swarms and complexes in southern Africa - regional extensional events and the origin of the Bushveld Complex. LITHOLUND theses 22, PhD, Lund University.

Olsson, J.R., Söderlund, U., Klausen, M.B. \& Ernst, R.E., 2010: U-Pb baddeleyite ages linking major Archean dyke swarms to volcanic rift-forming events in the Kaapvaal craton (South Africa), and a precise age of the Bushveld complex. Precambrian Research 183, 490-500.

Olsson, J.R., Söderlund, U., Hamilton, M.A., Klausen, M.B. \& Helffrich, G.R., 2011: A late Archaean radiating dyke swarm as possible clue to the origin of the Bushveld Complex. Nature Geoscience 4, 865-869.

Pearce, J., 2008: Geochemical fingerprinting of oceanic basalts with applications to ophiolite classification and the search for Archean oceanic crust. Lithos $100,14-48$.

Poujol, M., Robb, L.J., Respaut, J.P. \& Anhaeusser, C.R., 1996: 3.07-2.97 Ga greenstone belt formation in the northeastern Kaapvaal Craton: implications for the origin of the Witwatersrand Basin. Economic Geology 91, 1455-1461.

Poujol, M. \& Robb, L.J., 1999: New U-Pb zircon ages on gneisses and pegmatite from south of the Murchison greenstone belt, South Africa. South African Journal of Geology 102, 93-97.

Ragland, P.C., 1989: Basic analytical petrology. Oxford University Press, New York, 369 pp.

Ramokate, L.V., Mapeo, R.B.M., Corfu, F. \& Kampunzu, A.B., 2000: Proterozoic geology and regional correlation of the Ghanzi-Makunda area, western Botswana. Journal of African Earth Sciences 30, 453-466.

Ranganai, R.T., Kampunzu, A.B., Atekwana, E.A., Paya, B.K., King, J.G., Koosimile, D.I. \& Stettler, E.H., 2002: Gravity evidence for a larger Limpopo Belt in southern Africa and geodynamic implications. Geophysical Journal International 149, F9-F14.

Rasmussen, B. \& Fletcher, I.R., 2002: Indirect dating of mafic intrusions by SHRIMP U-Pb analysis of monazite in contact metamorphosed shale: an example from the Palaeoproterozoic Capricorn Orogen, Western Australia. Earth and Planetary Science Letters 197, 287-299.

Reischmann, T. 1995: Precise U/Pb age determination with baddeleyite $\left(\mathrm{ZrO}_{2}\right)$, a case study from the Phalaborwa Igneous Complex, South Africa. South African Journal of Geology 98, 1-4.

Rigby, M.J., Basson, I.J., Kramers, J.D., Gräser, P. \& Mavimbela, P.K., 2011: The structural, metamorphic and temporal evolution of the country rocks surrounding Venetia Mine, Limpopo Belt, South Africa: Evidence for a single palaeoproterozoic tectono-metamorphic event with implications for a tectonic model. Precambrian Research 186, 51-69.

Robb, L.J., Brandl, G., Anhaeusser, C.R. \& Poujol, M., 2006: Archaean granitoid intrusions. In M.R. Johnson, C.R. Anhaeusser \& R.J. Thomas (eds.): The geology of South Africa, 57-94. Geological Society of South Africa, Johannesburg/Council for Geoscience, Pretoria.

Roering, C., van Reenen, D.D., Smit, C.A., Barton, J.M., Jr, de Beer, J.H., de Wit, M.J., Stettler, E.H., van Schalkwyk, J.F., Stevens, G. \& Pretorius, S.J., 1992: Tectonic model for the evolution of the Limpopo Belt. Precambrian Research $55,539-552$

Scoates, J.S. \& Friedman, R.M., 2008: Precise age of the platiniferous Merensky Reef, Bushveld Complex, South Africa, by the U-Pb zircon chemical abrasion ID-TIMS technique. Economic Geology 103, 465-471.

Silver, P.G., Fouch, M.J., Gao, S.S. \& Schmitz, M., 2004: Seismic anisotropy, mantle fabric, and the magmatic evolution of Precambrian southern Africa. South African Journal of Geology 107, 45-58.
Söderlund, U. \& Johansson, L., 2002: A simple way to extract baddeleyite $\left(\mathrm{ZrO}_{2}\right)$. Geochemistry Geophysics Geosystems 3, 1014. doi: http://dx.doi.org/10.1029/2001GC000212.

Söderlund, U., Hofmann, A., Klausen, M.B., Olsson, J.R., Ernst, R.E. \& Persson, P.-O., 2010: Towards a complete magmatic barcode for the Zimbabwe craton: Baddeleyite U-Pb dating of regional dolerite dyke swarms and sill complexes. Precambrian Research 183, 388-398.

Stacey, J.S. \& Kramers, J.D., 1975: Approximation of terrestrial lead isotope evolution by a two-stage model. Earth and Planetary Science Letters 26 , 207-221.

Stowe, C.W., 1986: Synthesis and interpretation of structures along the north-eastern boundary of the Namaqua Tectonic Province, South Africa. Transactions Geological Society of South Africa 89, 185-198.

Stubbs, H.M., Hall, R.P., Hughes, D.J. \& Nesbitt, R.W., 1999: Evidence for a high $\mathrm{Mg}$ andesitic parental magma to the East and West satellite dykes of the Great Dyke, Zimbabwe: a comparison with the continental tholeiitic Mashonaland sills. Journal of African Earth Sciences 28, 325-336.

Stubbs, H.M., 2000: The geochemistry and petrogenesis of Archean and Palaeoproterozoic dykes and sills of Zimbabwe. Unpublished Ph. D. thesis, University of Portsmouth, $347 \mathrm{pp}$

Sun, S.S. \& McDonough, W.F., 1989: Chemical and isotopic systematics of oceanic basalts; implications for mantle composition and processes. Geological Society of London Special Publication 42, 313-345.

Svensen, H., Corfu, F., Polteau, S., Hammer, Ø. \& Planke, S., 2012: Rapid magma emplacement in the Karoo Large Igneous Province. Earth and Planetary Science Letters 325-326, 1-9.

Taylor, S.R. \& McLennan, S.M., 1995: The geochemical evolution of the continental crust. Reviews of Geophysics 33, 241-265.

Uken, R. \& Watkeys, M.K., 1997: An interpretation of mafic dyke swarms and their relationship with major mafic magmatic events on the Kaapvaal Craton and Limpopo Belt. South African Journal of Geology 100, 341-348.

Van Niekerk, H.S., 2009: The origin of the Kheis Terrane and its relationship with the Archean Kaapvaal Craton and the Grenvillian Namaqua province in Southern Africa. Unpublised Ph. D. thesis, University of Johannesburg.

Van Schijndel, V., Cornell, D.H., Hoffmann, K.H. \& Frei, D., 2011: Three episodes of crustal development in the Rehoboth Province, Namibia. Geological Society of London Special Publication 357, 27-47.

Verwoerd, W.J., 2006: The Pilanesberg Alkaline Province. In M.R. Johnson, C.R Anhaeusser \& R.J. Thomas (eds.): The geology of South Africa, 381-393. Geological Society of South Africa Johannesburg/Council for Geoscience Pretoria.

Wabo, H., de Kock, M.O., Klausen, M.B., Söderlund, U. \& Beukes, N.J., this volume: Paleomagnetism and chronology of B-1 marginal sills of the Bushveld Complex from the eastern Kaapvaal craton, South Africa. GFF.

Wabo, H., de Kock, M.O., Humbert, F., Söderlund, U., this volume: New U-Pb age and paleomagnetic constraints from the Uitkomst Complex, South Africa: clues to the timing of intrusion. GFF.

Watkeys, M.K., 1984: The Precambrian geology of the Limpopo Belt north and west of Messina. Unpublished Ph. D. thesis, Univ Witwatersrand, Johannesburg, $349 \mathrm{pp}$.

Wilson, J.F., Jones, D.L. \& Kramers, J.D., 1987: Mafic dike swarms in Zimbabwe. Geological Association of Canada Special Paper 34, 433-444.

Zegers, T.E., de Wit, M.J., Dann, J. \& White, S.H., 1998: Vaalbara, Earth's oldest assembled continent? A combined structural, geochronological, and palaeomagnetic test. Terra Nova 10, 250-259.

\section{Appendix A}

\section{A.1. Geochronology - mineral extraction, analytical procedures and data reduction}

Mineral extraction. Mineral separation was carried out entirely in Lund, where about $1 \mathrm{~kg}$ of each dolerite sample was crushed with a sledge-hammer and then ground in a swing mill to near-powder state and suspended in water. The smallest and heaviest grains, including the baddeleyite grains, with sizes ranging from 30 to $200 \mu \mathrm{m}$, were separated from the rest of the sample using the Wilfley water-shaking table and following the technique of Söderlund and Johansson (2002). The heavy mineral concentrate was transferred to a Petri dish and the magnetic minerals were removed with a strong pencil magnet wrapped in plastic. Best-quality baddeleyite grains were selectively handpicked with a tweezer under binocular microscope and then transferred to a separate, clean Petri dish using a small handmade pipette. 


\section{A.1.2. ID-TIMS analytical procedures and data reduction}

U-Pb ID-TIMS was carried out at LIG at the Museum of Natural History in Stockholm and at JSGL at the University of Toronto. A brief review of the analytical procedures at each laboratory is described below. Isotopic compositions of the laboratory blanks are noted at the end of each section.

A.1.2.1. Laboratory of Isotope Geology. Baddeleyite separates of samples BCD1-12, BCD5-28, BCD5-78, BCD8-12, BCD8-14 and one fraction of BCD5-25/29 were analysed at LIG in Stockholm. The best-quality baddeleyite grains were transferred from the Petri dish to Teflon ${ }^{\circledR}$ dissolution bombs using handmade micropipettes. The grains were then carefully washed in hot $\sim 3 \mathrm{~N}$ nitric acid $\left(\mathrm{HNO}_{3}\right)$ and subsequently rinsed repeatedly in ultraclean $\mathrm{H}_{2} \mathrm{O}$. An approximate amount of one to two drops of a ${ }^{205} \mathrm{~Pb}^{233-236} \mathrm{U}$ tracer and 10 drops of a mixture of hydroflouric acid (HF) and $\mathrm{HNO}_{3}$ were added to the dissolution capsules. The capsules were then sealed into steel jackets and put in the oven at $205^{\circ} \mathrm{C}$ for $24 \mathrm{~h}$. After dissolution the samples were dried down on a hot plate at $\sim 100{ }^{\circ} \mathrm{C}$. The uranium and lead was purified using small $\left(50 \mu\right.$ l) Teflon ${ }^{\circledR}$ columns filled with pre-cleaned ion-exchange resin (Bio-Rad 200-400 Mesh Chloride). The Zr-Hf-REE- cut was washed out with $3.1 \mathrm{M} \mathrm{HCl}$ in several steps. Thereafter, $\mathrm{U}$ and $\mathrm{Pb}$ were collected into the Teflon ${ }^{\circledR}$ dissolution capsules by adding a total of $\sim 60$ drops of ultraclean $\mathrm{H}_{2} \mathrm{O}$ to each $\mathrm{U}-\mathrm{Pb}$ column. Eventually a small portion of phosphoric acid $\left(\mathrm{H}_{3} \mathrm{PO}_{4}\right)$ was added before the samples were dried down again on a hot plate. Each sample was re-dissolved in $2 \mu \mathrm{l}$ of silica gel (produced after the recipe of Gerstenberger \& Haase 1997) and then put on an out-gassed single rhenium filament using an automatic pipette and pre-cleaned pipette tips. U-Pb samples were analysed in a Finnigan Triton thermal ionisation multicollector mass spectrometer equipped with Faraday cups and an ETP Secondary Electron Multiplier. Intensities of ${ }^{204} \mathrm{~Pb}{ }^{205} \mathrm{~Pb}{ }^{206} \mathrm{~Pb}{ }^{207} \mathrm{~Pb}$ and ${ }^{208} \mathrm{~Pb}$ were analysed at filament temperatures at $1180-1220{ }^{\circ} \mathrm{C}$, while the measurement of ${ }^{233} \mathrm{U},{ }^{236} \mathrm{U}$ and ${ }^{238} \mathrm{U}$ was performed subsequently at filament temperatures exceeding $1350{ }^{\circ} \mathrm{C}$. An in-house excel spreadsheet (written by Per-Olof Persson, LIG) based on the algorithms of Ludwig (1991) was used to perform the $\mathrm{U}$ and $\mathrm{Pb}$ data reduction. The initial $\mathrm{Pb}$ composition was taken from Stacey and Kramers (1975) and the decay constants were according to Jaffey et al. (1971). Procedural blank levels at LIG are at $1.0 \mathrm{pg}$ for $\mathrm{Pb}$ and $0.2 \mathrm{pg}$ for U. The isotopic composition of LIG laboratory blank (errors at $2 \sigma$ ) is: ${ }^{206} \mathrm{~Pb} /{ }^{204} \mathrm{~Pb}=18.5$ (2) $20^{7} \mathrm{~Pb} /{ }^{204} \mathrm{~Pb}=15.6(0.2)$ and ${ }^{208} \mathrm{~Pb} /{ }^{204} \mathrm{~Pb}=38.5(0) .{ }^{205} \mathrm{~Pb} /{ }^{233-236} \mathrm{U}$ spike calibration with errors at $0.3 \%$ $(2 \sigma):{ }^{206} \mathrm{~Pb} /{ }^{205} \mathrm{~Pb}=0.000333{ }^{206} \mathrm{~Pb} /{ }^{204} \mathrm{~Pb}=7{ }^{206} \mathrm{~Pb} / 207 \mathrm{~Pb}=1.176470588$ ${ }^{206} \mathrm{~Pb} /{ }^{208} \mathrm{~Pb}=0.46728972$ and ${ }^{238} \mathrm{U} /{ }^{233} \mathrm{U}=0.0034602$.

A.1.2.2. Jack Satterly Geochronology Laboratory. Baddeleyite fractions for samples BCD1-18 and BCD1-21, and three fractions from BCD5-25/29, BCD5-85, BCD6-05, BCD8-13 and BCD8-15 were analysed at JSGL in Toronto. Fractions of baddeleyite grains of highest quality were selected and washed in small amounts of concentrated HF and $7 \mathrm{~N} \mathrm{HNO}_{3}$ on a piece of pre-cleaned Parafilm ${ }^{\circledR}$. The samples were rinsed in ultra-clean $\mathrm{H}_{2} \mathrm{O}$ and dried in a droplet of acetone. Washed baddeleyites were transferred in a droplet of $7 \mathrm{~N} \mathrm{HNO}_{3}$ to Teflon ${ }^{\circledR}$ dissolution capsules, to which twelve drops of concentrated HF and one droplet of mixed ${ }^{205} \mathrm{~Pb}-{ }^{235} \mathrm{U}$ tracer were added. Capsules were placed in steel jackets and put in an oven at $195{ }^{\circ} \mathrm{C}$ for $72 \mathrm{~h}$ to ensure complete dissolution. Following dissolution, the samples were dried down on a hot plate, re-dissolved in 10 drops of $3 \mathrm{~N} \mathrm{HCl}$ and placed in the oven for a further $24 \mathrm{~h}$. Chloride-converted samples were then loaded directly onto outgassed single rhenium filaments together with a small amount of silica gel (modified from the recipe of Gerstenberger \& Haase 1997). Ion-exchange column chemistry was not carried out on these small fractions. The U-Pb samples were analysed on a VG354 mass spectrometer coupled with a Daly detector where the intensities of ${ }^{204} \mathrm{~Pb}{ }^{205} \mathrm{~Pb}$ ${ }^{206} \mathrm{~Pb}{ }^{207} \mathrm{~Pb}$ and ${ }^{208} \mathrm{~Pb}$ were measured in a step-wise mode in temperature intervals of $1370-1470{ }^{\circ} \mathrm{C}$. The uranium isotope intensities $\left({ }^{235} \mathrm{U}\right.$ and ${ }^{238} \mathrm{U}$ ) were measured in a similar procedure at filament temperatures of $1490-1530{ }^{\circ} \mathrm{C}$. The $\mathrm{U}-\mathrm{Pb}$ data reduction was performed using an in-house program (UtilAge). Corrections for Daly mass discrimination were $0.07 \%$ /atomic mass unit (amu) and $0.10 \%$ /amu for thermal mass discrimination. The procedural blank levels at JSGL are typically $0.5 \mathrm{pg}$ for $\mathrm{Pb}$ and $0.1 \mathrm{pg}$ for $\mathrm{U}$. The isotopic composition of the laboratory blank is ${ }^{206} \mathrm{~Pb} /{ }^{204} \mathrm{~Pb}: 18.221 ;{ }^{207} \mathrm{~Pb} /{ }^{204} \mathrm{~Pb}: 15.612 ;{ }^{208} \mathrm{~Pb} /{ }^{204} \mathrm{~Pb}: 39.360$. For calculations of $\mathrm{U}-\mathrm{Pb}$ ages, the decay constants for ${ }^{235} \mathrm{U}$ and ${ }^{238} \mathrm{U}$ were taken from Jaffey et al. (1971) with initial $\mathrm{Pb}$ compositions $\left({ }^{206} \mathrm{~Pb} /{ }^{204} \mathrm{~Pb}\right.$ : $13.660 ;{ }^{207} \mathrm{~Pb} /{ }^{204} \mathrm{~Pb}: 14.700 ;{ }^{208} \mathrm{~Pb} /{ }^{204} \mathrm{~Pb}$ : 33.386$)$ from Stacey and Kramers (1975).

\section{A.2. Geochemistry - sample preparation and analytical techniques}

The majority of the whole-rock major and trace element analyses was performed at ACME laboratory in Vancouver (Canada). However, some samples were also processed in Stellenbosch University (BCD585, BCD6-05 and BCD8-13) and University of Pretoria (BCD8-12) in South Africa. Although the procedures of the laboratories are only slightly different, we will shortly review the sample preparation and analytical procedures of Stellenbosch University's Central Analytical Facilities and the geochemical laboratory at the University of Pretoria in South Africa. The reader is referred to ACME laboratory for details on their analytical procedures. All samples except BCD8-12 (processed in Pretoria) was crushed and milled in a tungsten-carbide (WC) swing mill in the mineral preparation laboratory at the Geological department, Lund University.

\section{A.2.1. Stellenbosch University Central Analytical Facilities}

At Stellenbosch University, major element compositions are analysed as oxides in weight per cent by X-ray Fluorescence analysis (XRF) on Lafree fused glass beads using a Phillip's PW1404w instrument coupled with a scintillation or gas flow proportional counting detector (detection limits $\sim 0.001 \mathrm{wt} \%$ ). For calibration and quality control international (NIST $\left.{ }^{\circledR}\right)$ and national (SARM $\left.{ }^{\circledR}\right)$ standards were analysed in between sample runs. An Agilent 7500ce Laser Ablation (LA) - Inductively Coupled Plasma Mass Spectrometry (ICPMS) was used to obtain trace element compositions in ppm on the same glass beads. A total of three spot analyses are averaged for every trace element determination and the standard of NIST612 was used for calibration. Data reduction was performed using an Excel calculation spreadsheet with $\mathrm{SiO}_{2}$ (measured by XRF) as internal standard. The reproducibility and deviations from certified values are usually better than $10 \%$ and below $5 \%$ relative for trace element determinations.

\section{A.2.2. University of Pretoria}

The dyke sample BCD8-12 intruding the Bushveld Complex was analysed in the XRD and XRF facility at the Geology department, University of Pretoria in South Africa. Here a WC milling vessel was used to ground and mill the sample to a fine-grained fraction. The sample was roasted at $1000{ }^{\circ} \mathrm{C}$ to determine loss on ignition. One gram of sample was then added to $6 \mathrm{~g} \mathrm{Li}_{2} \mathrm{~B}_{4} \mathrm{O}_{7}$ and fused into a glass bead and major elements were analysed using a ARL9400XP + spectrometer. Trace elements were analysed from another aliquot of the sample that was pressed in a powder briquette. Certified reference material and standards (GSNcert) were also analysed with the sample. 


\section{Appendix B}

Table 1. U-Pb baddeleyite data.

\begin{tabular}{|c|c|c|c|c|c|c|c|c|c|c|c|c|c|c|c|c|}
\hline & & & & $\mathrm{Th} /$ & $\mathrm{Pb}^{*} /$ & ${ }^{206} \mathrm{~Pb} /$ & ${ }^{207} \mathrm{~Pb} /$ & $\pm 2 \sigma$ & ${ }^{206} \mathrm{~Pb} /$ & $\pm 2 \sigma$ & Corr. & ${ }^{206} \mathrm{~Pb} /$ & ${ }^{207} \mathrm{~Pb} /$ & ${ }^{207} \mathrm{~Pb} /$ & $\pm 2 \sigma$ & Discord- \\
\hline \multirow[t]{2}{*}{ Lab. } & Sample & Fraction & $n^{\mathrm{a}}$ & $\mathrm{U}^{\mathrm{b}}$ & $\mathrm{Pbc}^{\mathrm{c}}$ & ${ }^{204} \mathrm{~Pb}$ & ${ }^{235} \mathrm{U}$ & $\%$ err & ${ }^{238} \mathrm{U}$ & $\%$ err & \multirow[t]{2}{*}{ coeff. } & ${ }^{238} \mathrm{U}$ & ${ }^{235} \mathrm{U}$ & ${ }^{206} \mathrm{~Pb}$ & $\mathrm{Ma}$ & \multirow{2}{*}{$\begin{array}{c}\text { ance } \\
\%\end{array}$} \\
\hline & & & & & & meas $^{d}$ & \multicolumn{4}{|c|}{$\left[\right.$ corr] ${ }^{\mathrm{e}}$} & & \multicolumn{4}{|c|}{ [Age, Ma] } & \\
\hline \multirow{23}{*}{$\begin{array}{l}\text { JSGL, } \\
\text { Toronto }\end{array}$} & \multirow[t]{3}{*}{ BCD1-18 } & A & 4 & 0.207 & 9.7 & 701 & 5.0878 & 0.8631 & 0.32585 & 0.28676 & 0.6639 & 1818.3 & 1834.1 & 1852.1 & 12.8 & 2.1 \\
\hline & & B & 2 & 0.306 & 27.2 & 1771 & 5.0853 & 0.4220 & 0.32626 & 0.24424 & 0.7524 & 1820.2 & 1833.7 & 1848.9 & 5.2 & 1.8 \\
\hline & & $\mathrm{C}$ & 3 & 0.164 & 84.0 & 5482 & 5.0620 & 0.2840 & 0.32485 & 0.22828 & 0.9130 & 1813.4 & 1829.8 & 1848.5 & 2.2 & 2.2 \\
\hline & \multirow[t]{4}{*}{ BCD1-21 } & A & 3 & 0.100 & 12.3 & 887 & 5.1894 & 0.7810 & 0.32911 & 0.47269 & 0.6692 & 1834.1 & 1850.9 & 1869.8 & 10.5 & 2.2 \\
\hline & & B & 2 & 0.069 & 9.4 & 701 & 5.2398 & 1.2060 & 0.33241 & 0.89308 & 0.8144 & 1850.1 & 1859.1 & 1869.2 & 12.8 & 1.2 \\
\hline & & $\mathrm{C}$ & 4 & 0.133 & 12.9 & 916 & 5.4471 & 0.7973 & 0.34597 & 0.49916 & 0.7281 & 1915.3 & 1892.3 & 1867.1 & 10.0 & -3.0 \\
\hline & & D & 4 & 0.209 & 21.5 & 1446 & 5.2484 & 0.5679 & 0.33231 & 0.39569 & 0.7990 & 1849.6 & 1860.5 & 1872.8 & 6.3 & 1.4 \\
\hline & \multirow[t]{3}{*}{ BCD5-25/29 } & A & 4 & 0.040 & 18.5 & 1309 & 5.1527 & 0.5126 & 0.32870 & 0.26033 & 0.6938 & 1832.1 & 1844.8 & 1859.3 & 6.9 & 1.7 \\
\hline & & B & 2 & 0.022 & 34.2 & 2363 & 5.2191 & 0.3736 & 0.33254 & 0.25989 & 0.7944 & 1850.7 & 1855.7 & 1861.4 & 4.2 & 0.7 \\
\hline & & $\mathrm{C}$ & 3 & 0.069 & 35.0 & 2387 & 5.2233 & 0.5040 & 0.33329 & 0.43069 & 0.8918 & 1854.3 & 1856.4 & 1858.8 & 4.1 & 0.3 \\
\hline & \multirow[t]{2}{*}{ BCD5-85 } & A & 1 & 0.183 & 12.6 & 887 & 5.2146 & 0.8514 & 0.33298 & 0.53904 & 0.7469 & 1852.8 & 1855.0 & 1857.5 & 10.4 & 0.3 \\
\hline & & B & 3 & 0.201 & 6.2 & 476 & 5.1388 & 1.3837 & 0.32851 & 0.68112 & 0.6741 & 1831.1 & 1842.5 & 1855.4 & 19.1 & 1.5 \\
\hline & \multirow[t]{5}{*}{ BCD6-05 } & A & 1 & 0.011 & 1.6 & 195 & 5.1739 & 3.2371 & 0.33079 & 0.94593 & 0.6574 & 1842.2 & 1848.3 & 1855.2 & 49.5 & 0.8 \\
\hline & & B & 3 & 0.010 & 2.5 & 253 & 5.1402 & 2.4223 & 0.32922 & 0.63625 & 0.6770 & 1834.6 & 1842.8 & 1852.0 & 37.3 & 1.1 \\
\hline & & $\mathrm{C}$ & 3 & 0.047 & 13.6 & 985 & 5.1713 & 1.1618 & 0.33017 & 0.95614 & 0.8678 & 1839.2 & 1847.9 & 1857.7 & 10.5 & 1.1 \\
\hline & & $\mathrm{D}$ & 3 & 0.008 & 10.6 & 796 & 5.0317 & 1.0891 & 0.32338 & 0.73793 & 0.7723 & 1806.2 & 1824.7 & 1845.8 & 12.7 & 2.5 \\
\hline & & E & 3 & 0.005 & 5.2 & 433 & 5.1701 & 1.6976 & 0.33275 & 1.01380 & 0.7081 & 1851.7 & 1847.7 & 1843.2 & 22.0 & -0.5 \\
\hline & \multirow{6}{*}{$\begin{array}{l}\text { BCD8-13 } \\
\text { Foskor }\end{array}$} & A & 3 & 0.157 & 19.2 & 1322 & 4.9341 & 0.5788 & 0.32124 & 0.35885 & 0.7481 & 1795.8 & 1808.1 & 1822.3 & 7.1 & 1.7 \\
\hline & & B & 2 & 0.074 & 24.8 & 1717 & 5.0729 & 0.6206 & 0.32769 & 0.51630 & 0.8687 & 1827.2 & 1831.6 & 1836.6 & 5.6 & 0.6 \\
\hline & & $\mathrm{C}$ & 3 & 0.083 & 82.0 & 5464 & 5.0337 & 0.2730 & 0.32535 & 0.21514 & 0.9030 & 1815.8 & 1825.0 & 1835.5 & 2.2 & 1.2 \\
\hline & & $\mathrm{D}$ & 3 & 0.043 & 21.5 & 1512 & 4.8447 & 0.5566 & 0.31444 & 0.37926 & 0.7795 & 1762.5 & 1792.7 & 1828.0 & 6.4 & 4.1 \\
\hline & & E & 2 & 0.064 & 35.0 & 2392 & 5.0169 & 0.5198 & 0.32424 & 0.44704 & 0.9000 & 1810.4 & 1822.2 & 1835.7 & 4.1 & 1.6 \\
\hline & & $\mathrm{F}$ & 4 & 0.120 & 19.2 & 1330 & 5.0433 & 0.5316 & 0.32567 & 0.28921 & 0.7157 & 1817.3 & 1826.6 & 1837.2 & 6.9 & 1.2 \\
\hline \multirow{21}{*}{$\begin{array}{l}\text { LIG, } \\
\text { Stock- } \\
\text { holm }\end{array}$} & \multirow[t]{4}{*}{ BCD1-12 } & A & 11 & 0.125 & 6.8 & 418 & 5.0013 & 0.4968 & 0.32064 & 0.38945 & 0.7950 & 1792.8 & 1819.5 & 1850.2 & 5.5 & 3.1 \\
\hline & & B & 3 & 0.103 & 5.4 & 360 & 4.6167 & 0.8136 & 0.29742 & 0.79122 & 0.9420 & 1678.5 & 1752.3 & 1841.5 & 5.0 & 8.8 \\
\hline & & $\mathrm{C}$ & 3 & 0.104 & 4.4 & 291 & 4.8561 & 0.6161 & 0.31276 & 0.58550 & 0.9241 & 1754.3 & 1794.7 & 1841.9 & 4.3 & 4.8 \\
\hline & & $\mathrm{D}$ & 1 & 0.091 & 2.7 & 213 & 5.0646 & 2.2279 & 0.32529 & 2.19496 & 0.9488 & 1815.5 & 1830.2 & 1846.9 & 12.8 & 1.7 \\
\hline & BCD5-25/29 & $\mathrm{D}$ & 6 & n.d. & 3.1 & 227 & 5.0836 & 0.7416 & 0.32318 & 0.65343 & 0.8975 & 1805.2 & 1833.4 & 1865.5 & 5.9 & 3.2 \\
\hline & \multirow[t]{4}{*}{ BCD5-28 } & A & 4 & 0.113 & 9.8 & 612 & 4.9729 & 0.4896 & 0.31799 & 0.42750 & 0.8837 & 1779.9 & 1814.7 & 1855.0 & 4.1 & 4.0 \\
\hline & & B & 6 & 0.182 & 12.2 & 741 & 5.0122 & 0.3446 & 0.31989 & 0.27691 & 0.8195 & 1789.2 & 1821.4 & 1858.4 & 3.6 & 3.7 \\
\hline & & $\mathrm{C}$ & 4 & 0.153 & 4.1 & 264 & 4.7660 & 0.7286 & 0.30493 & 0.47102 & 0.7133 & 1715.7 & 1778.9 & 1853.9 & 9.3 & 7.5 \\
\hline & & $\mathrm{D}$ & 5 & 0.168 & 5.3 & 340 & 4.7058 & 0.5502 & 0.30166 & 0.47969 & 0.8639 & 1699.5 & 1768.3 & 1850.4 & 5.0 & 8.2 \\
\hline & \multirow[t]{4}{*}{ BCD5-78 } & A & 10 & 0.082 & 28.1 & 1717 & 4.9507 & 0.2263 & 0.31772 & 0.20345 & 0.9049 & 1778.6 & 1810.9 & 1848.4 & 1.7 & 3.8 \\
\hline & & B & 2 & 0.115 & 8.9 & 599 & 5.0834 & 0.9191 & 0.32619 & 0.88889 & 0.9374 & 1819.9 & 1833.3 & 1848.6 & 5.8 & 1.6 \\
\hline & & $\mathrm{C}$ & 2 & 0.060 & 12.7 & 842 & 4.9727 & 0.6274 & 0.31960 & 0.60451 & 0.9369 & 1787.8 & 1814.7 & 1845.7 & 4.0 & 3.1 \\
\hline & & $\mathrm{D}$ & 2 & 0.121 & 2.1 & 154 & 5.0442 & 1.4559 & 0.32417 & 1.39671 & 0.9263 & 1810.1 & 1826.8 & 1845.8 & 10.0 & 1.9 \\
\hline & \multirow{4}{*}{$\begin{array}{c}\text { BCD8-12 } \\
\text { NKWE }\end{array}$} & A & 2 & 0.172 & 1.5 & 122 & 5.1944 & 2.4545 & 0.33599 & 2.39187 & 0.9361 & 1867.3 & 1851.7 & 1834.2 & 15.7 & -1.8 \\
\hline & & B & 2 & n.d. & 1.4 & 139 & 5.1683 & 3.2339 & 0.33525 & 3.18290 & 0.9461 & 1863.8 & 1847.4 & 1829.0 & 19.1 & -1.9 \\
\hline & & $\mathrm{C}$ & 5 & 0.121 & 4.3 & 280 & 5.0784 & 0.6162 & 0.32690 & 0.52986 & 0.8471 & 1823.4 & 1832.5 & 1842.9 & 5.9 & 1.1 \\
\hline & & $\mathrm{D}$ & 5 & 0.153 & 8.1 & 506 & 5.1204 & 0.5475 & 0.32914 & 0.53279 & 0.9567 & 1834.2 & 1839.5 & 1845.5 & 2.9 & 0.6 \\
\hline & BCD8-14 & A & 5 & 0.056 & 57.7 & 3518 & 5.0055 & 0.1475 & 0.32174 & 0.13183 & 0.8971 & 1798.2 & 1820.3 & 1845.6 & 1.2 & 2.6 \\
\hline & & B & 4 & 0.109 & 15.1 & 927 & 4.8972 & 0.3259 & 0.31567 & 0.28024 & 0.8706 & & & & & \\
\hline & & $\mathrm{C}$ & 5 & 0.056 & 45.4 & 2783 & 4.9263 & 0.1640 & 0.31712 & 0.14210 & 0.8699 & & & & & \\
\hline & & D & 2 & 0.164 & 7.4 & 487 & 5.0487 & 0.8143 & 0.32489 & 0.77257 & 0.9221 & & & & & \\
\hline
\end{tabular}

${ }^{\mathrm{a}} n=$ number of baddeleyite crystals.

${ }^{\mathrm{b}} \mathrm{Th} / \mathrm{U}$ model ratio inferred from ${ }^{208} \mathrm{~Pb} /{ }^{206} \mathrm{~Pb}$ ratio and age of sample.

${ }^{\mathrm{c}} \mathrm{Pb}^{*}=$ radiogenic lead; $\mathrm{Pbc}=$ total common lead (initial + blank lead).

${ }^{\mathrm{d}}$ measured ratio, corrected for fractionation and spike.

eisotopic ratios corrected for fractionation $(0.1 \%$ per amu for $\mathrm{Pb}$ [LIG]), spike calibration, blank and residual initial common $\mathrm{Pb}$.

Initial common $\mathrm{Pb}$ corrected with isotopic compositions from the model of Stacey and Kramers (1975) for the age of the sample.

Procedural blank levels at LIG (Stockholm) were $1.0 \mathrm{pg}$ for $\mathrm{Pb}$ and 0.2119 for $\mathrm{U}$ at the time these analyses were performed, and typically at $0.5 \mathrm{pg}$ for $\mathrm{Pb}$ and $0.1 \mathrm{pg}$ for $\mathrm{U}$ at JSGL. 


\section{Appendix C}

Table 2. Major and trace element geochemistry of Kaapvaal dykes and Mashonaland sills.

\begin{tabular}{|c|c|c|c|c|c|c|c|c|c|c|c|c|c|}
\hline Sample & $\begin{array}{c}\text { BCD1- } \\
12\end{array}$ & $\begin{array}{c}\text { BCD1- } \\
18\end{array}$ & \begin{tabular}{|c} 
BCD1- \\
21
\end{tabular} & $\begin{array}{c}\text { BCD5- } \\
25\end{array}$ & $\begin{array}{c}\text { BCD5- } \\
28\end{array}$ & $\begin{array}{c}\text { BCD5- } \\
29\end{array}$ & $\begin{array}{c}\text { BCD5- } \\
78\end{array}$ & $\begin{array}{c}\text { BCD5- } \\
85\end{array}$ & $\begin{array}{c}\text { BCD6- } \\
05\end{array}$ & $\begin{array}{c}\text { BCD8- } \\
12\end{array}$ & $\begin{array}{c}\text { BCD8- } \\
13\end{array}$ & $\begin{array}{c}\text { BCD8- } \\
14\end{array}$ & $\begin{array}{c}\text { BCD5- } \\
55\end{array}$ \\
\hline $\mathrm{SiO}_{2}$ & 50.25 & 48.48 & 50.34 & 49.65 & 49.01 & 49.36 & 49.73 & 48.72 & 48.57 & 49.41 & 49.77 & 48.57 & 49.58 \\
\hline $\mathrm{Al}_{2} \mathrm{O}_{3}$ & 15.01 & 12.66 & 13.89 & 14.88 & 14.7 & 16.46 & 13.12 & 13.67 & 12.41 & 13.25 & 12.56 & 11.22 & 16.37 \\
\hline $\mathrm{Fe}_{2} \mathrm{O}_{3}$ & 13.96 & 17.6 & 14.14 & 10.7 & 13.88 & 10.36 & 15.96 & 15.15 & 17.02 & 17.37 & 16.47 & 20.14 & 13.97 \\
\hline $\mathrm{MgO}$ & 5.22 & 4.99 & 6.75 & 9.41 & 7.3 & 8.24 & 5.65 & 6.77 & 5.52 & 5.00 & 5.20 & 4.18 & 4.48 \\
\hline $\mathrm{CaO}$ & 9.19 & 9.15 & 10.49 & 11.15 & 10.42 & 11.6 & 9.57 & 9.89 & 9.45 & 9.49 & 9.43 & 8.28 & 9.48 \\
\hline $\mathrm{Na}_{2} \mathrm{O}$ & 2.77 & 2.3 & 2.15 & 1.71 & 2.25 & 1.79 & 2.19 & 2.10 & 1.99 & 1.94 & 2.11 & 2.18 & 2.84 \\
\hline $\mathrm{K}_{2} \mathrm{O}$ & 0.93 & 0.82 & 0.45 & 0.26 & 0.35 & 0.29 & 0.75 & 0.42 & 0.76 & 0.73 & 0.65 & 1.14 & 0.86 \\
\hline $\mathrm{TiO}_{2}$ & 1.66 & 2.58 & 1.15 & 0.84 & 1.31 & 0.77 & 2.03 & 1.70 & 2.40 & 2.40 & 2.11 & 3.01 & 1.72 \\
\hline $\mathrm{MnO}$ & 0.19 & 0.23 & 0.2 & 0.17 & 0.2 & 0.16 & 0.21 & 0.22 & 0.24 & 0.22 & 0.23 & 0.25 & 0.18 \\
\hline $\mathrm{P}_{2} \mathrm{O}_{5}$ & 0.2 & 0.26 & 0.11 & 0.11 & 0.14 & 0.08 & 0.25 & 0.20 & 0.27 & 0.27 & 0.21 & 0.45 & 0.22 \\
\hline L.O.I. & 0.3 & 0.6 & 0 & 0.8 & 0.1 & 0.6 & 0.2 & 0.39 & 0.7 & 0.32 & 0.53 & 0.2 & 0 \\
\hline Tot. & 99.71 & 99.67 & 99.72 & 99.73 & 99.72 & 99.75 & 99.69 & 99.32 & 99.39 & 100.42 & 99.29 & 99.61 & 99.74 \\
\hline $\mathrm{Sc}$ & 33.00 & 40.00 & 45.00 & 39.00 & 41.00 & 36.00 & 42.00 & 41.77 & 44.80 & 30.03 & 47.41 & 43.00 & 32.00 \\
\hline $\mathrm{V}$ & 317.00 & 461.00 & 316.00 & 250.00 & 341.00 & 236.00 & 370.00 & 358.32 & 453.15 & 359.36 & 450.64 & 453.00 & 316.00 \\
\hline $\mathrm{Cr}$ & 54.74 & 61.58 & 136.84 & 355.79 & 260.00 & 287.37 & 109.47 & 183.85 & 87.50 & 69.50 & 86.31 & 41.05 & 68.40 \\
\hline $\mathrm{Co}$ & 43.70 & 49.50 & 54.10 & 48.10 & 52.80 & 45.80 & 51.80 & 53.85 & 49.76 & 57.76 & 59.89 & 57.90 & 41.30 \\
\hline $\mathrm{Ni}$ & 89.00 & 60.00 & 87.00 & 159.00 & 110.00 & 136.00 & 74.00 & 111.83 & 70.42 & 65.63 & 59.59 & 44.00 & 55.00 \\
\hline $\mathrm{Cu}$ & 148.70 & 376.10 & 163.70 & 109.40 & 187.90 & 119.40 & 220.40 & 156.96 & 209.18 & 301.52 & 169.79 & 389.00 & 250.60 \\
\hline $\mathrm{Cs}$ & 0.80 & 1.40 & 1.10 & 0.90 & 1.30 & 1.20 & 1.60 & 1.55 & 2.55 & 10.52 & 0.95 & 2.10 & 0.60 \\
\hline $\mathrm{Rb}$ & 28.10 & 33.00 & 13.80 & 10.10 & 12.70 & 15.10 & 26.90 & 13.16 & 30.32 & 34.19 & 27.03 & 52.10 & 26.80 \\
\hline $\mathrm{Sr}$ & 212.10 & 152.60 & 168.40 & 126.70 & 132.20 & 144.50 & 143.90 & 171.32 & 174.82 & 154.66 & 177.26 & 182.80 & 174.10 \\
\hline $\mathrm{Y}$ & 31.70 & 44.60 & 23.50 & 16.60 & 27.50 & 14.70 & 37.50 & 30.37 & 41.38 & 54.08 & 41.24 & 62.30 & 31.50 \\
\hline $\mathrm{Zr}$ & 140.20 & 202.10 & 79.40 & 53.80 & 92.20 & 46.50 & 164.90 & 131.35 & 173.08 & 223.81 & 166.80 & 292.70 & 145.20 \\
\hline $\mathrm{Nb}$ & 8.20 & 13.60 & 4.70 & 3.10 & 5.10 & 2.40 & 10.60 & 8.78 & 11.20 & 16.63 & 11.62 & 18.50 & 8.80 \\
\hline $\mathrm{Ba}$ & 258.00 & 188.00 & 145.00 & 65.00 & 97.00 & 67.00 & 199.00 & 150.32 & 195.02 & 191.04 & 115.51 & 251.00 & 214.00 \\
\hline $\mathrm{La}$ & 17.90 & 18.90 & 9.30 & 5.50 & 8.20 & 4.70 & 17.20 & 14.55 & 19.31 & 8.48 & 15.06 & 27.00 & 16.70 \\
\hline $\mathrm{Ce}$ & 39.90 & 46.70 & 20.40 & 12.70 & 20.00 & 10.70 & 40.10 & 30.71 & 40.08 & 26.50 & 32.88 & 64.70 & 37.60 \\
\hline $\operatorname{Pr}$ & 5.10 & 5.83 & 2.79 & 1.74 & 2.77 & 1.50 & 5.12 & 4.17 & 5.46 & n.d. & 4.67 & 8.22 & 4.71 \\
\hline $\mathrm{Nd}$ & 21.20 & 26.90 & 12.30 & 8.00 & 13.90 & 7.10 & 23.30 & 19.06 & 24.79 & n.d. & 22.45 & 38.40 & 20.60 \\
\hline $\mathrm{Sm}$ & 4.86 & 6.72 & 3.14 & 2.03 & 3.35 & 1.86 & 5.69 & 5.03 & 6.35 & n.d. & 5.24 & 9.40 & 4.96 \\
\hline $\mathrm{Eu}$ & 1.55 & 2.03 & 1.09 & 0.79 & 1.15 & 0.71 & 1.76 & 1.55 & 1.88 & n.d. & 1.88 & 2.68 & 1.57 \\
\hline $\mathrm{Gd}$ & 5.58 & 7.83 & 3.63 & 2.63 & 4.20 & 2.31 & 6.59 & 5.47 & 7.12 & n.d. & 7.41 & 11.05 & 5.68 \\
\hline $\mathrm{Tb}$ & 0.94 & 1.40 & 0.68 & 0.48 & 0.77 & 0.41 & 1.20 & 0.89 & 1.19 & n.d. & 1.21 & 1.98 & 1.01 \\
\hline Dy & 5.57 & 8.37 & 4.15 & 2.94 & 4.68 & 2.58 & 6.91 & 5.81 & 7.72 & n.d. & 7.69 & 11.66 & 6.13 \\
\hline Ho & 1.15 & 1.75 & 0.85 & 0.60 & 1.00 & 0.54 & 1.50 & 1.19 & 1.60 & n.d. & 1.62 & 2.46 & 1.22 \\
\hline $\mathrm{Er}$ & 3.35 & 5.18 & 2.60 & 1.76 & 2.96 & 1.52 & 4.35 & 3.45 & 4.72 & n.d. & 4.68 & 6.98 & 3.55 \\
\hline $\mathrm{Tm}$ & 0.47 & 0.75 & 0.39 & 0.28 & 0.44 & 0.25 & 0.66 & 0.50 & 0.66 & n.d. & 0.66 & 1.08 & 0.53 \\
\hline $\mathrm{Yb}$ & 3.07 & 5.14 & 2.43 & 1.69 & 2.79 & 1.50 & 4.10 & 3.25 & 4.60 & n.d. & 4.53 & 6.83 & 3.42 \\
\hline $\mathrm{Lu}$ & 0.45 & 0.74 & 0.36 & 0.25 & 0.42 & 0.23 & 0.64 & 0.48 & 0.63 & n.d. & 0.66 & 1.03 & 0.52 \\
\hline Hf & 3.80 & 5.30 & 2.20 & 1.60 & 2.60 & 1.30 & 4.60 & 3.46 & 4.83 & n.d. & 4.77 & 7.60 & 4.20 \\
\hline $\mathrm{Ta}$ & 0.50 & 0.90 & 0.30 & 0.20 & 0.30 & 0.10 & 0.70 & 0.58 & 0.71 & n.d. & 0.74 & 1.30 & 0.60 \\
\hline $\mathrm{Pb}$ & 2.80 & 4.20 & 1.80 & 1.00 & 1.50 & 1.00 & 3.40 & 3.54 & 7.82 & 8.63 & 3.21 & 5.90 & 3.00 \\
\hline Th & 2.90 & 3.90 & 1.90 & 1.00 & 1.70 & 0.70 & 4.30 & 2.05 & 3.67 & 15.22 & 2.16 & 6.50 & 3.70 \\
\hline $\mathrm{U}$ & 0.60 & 1.30 & 0.40 & 0.30 & 0.50 & 0.20 & 1.20 & 0.50 & 0.84 & 10.87 & 0.50 & 1.90 & 0.80 \\
\hline $\mathrm{Ga}$ & 19.60 & 20.20 & 16.70 & 14.30 & 17.10 & 14.50 & 19.10 & n.d. & n.d. & 19.86 & n.d. & 21.70 & 19.90 \\
\hline
\end{tabular}

